\title{
THE
}

\section{Topical Themes from the Oberkampf Textile Manufactory, Jouy- en-Josas, France, 1760-1821}

Aziza Gril-Mariotte

Pamela J. Warner

University of Rhode Island, pwarner@mail.uri.edu

Follow this and additional works at: https://digitalcommons.uri.edu/art_facpubs

Terms of Use

All rights reserved under copyright.

\section{Citation/Publisher Attribution}

Gril-Mariotte, Aziza. "Topical Themes from the Oberkampf Textile Manufactory, Jouy-en-Josas, France, 1760-1821." Translated by Pamela J. Warner. Studies in the Decorative Arts 17 (2009): 162-97. Available at: http://www.jstor.org/stable/10.1086/652667.

This Article is brought to you for free and open access by the Art and Art History at DigitalCommons@URI. It has been accepted for inclusion in Art and Art History Faculty Publications by an authorized administrator of DigitalCommons@URI. For more information, please contact digitalcommons-group@uri.edu. 


\section{Topical Themes from the Oberkampf Textile Manufactory, Jouy-en-Josas, France, $1760-1821$}

The development of printing in the eighteenth century facilitated the diffusion of current political, scientific, cultural, and artistic events. While newspapers and gazettes remained products largely reserved for the upper classes because of the cost of subscriptions, they were nevertheless also read by domestic servants, merchants, and students, and in cafés. ${ }^{1}$ Certain sensational incidents were illustrated and publicized in engravings or popular imagery such as broadside woodcuts and lithographs, and sometimes painters would seize on them as such incidents became a source of inspiration in high art.

Through their interest in certain events, engravers and artists both provoked and participated in veritable fads. To satisfy the consumer's curiosity and tastes, decorative artists also appropriated current events as subjects and exploited the contents of newspapers, engravings, and paintings. The industry of printed fabrics that developed in France beginning in $1759^{2}$ did not escape this trend, especially since production techniques permitted the frequent updating of compositions and the introduction of new ones. Political and cultural happenings are represented most notably in the monochromes printed from copperplates on textiles for interior design and clothing. ${ }^{3}$ Monochrome upholstery, called camayeux meuble, constitutes a category of printed textiles that customers appreciated for their figurative depictions in decorative ensembles. These fabrics were produced in large factories, which were sufficiently financed to be able to acquire topical designs, to print from copperplates, and to employ specialized workers. From c. 1760 to c. 1821 the textile factory at Jouy-en-Josas west of Paris distinguished itself with the creation of large figurative designs depicting important occurrences of the time in order to appeal to their buyers.

The Jouy factory was founded in 1760 to produce printed cottons by Christophe-Philippe Oberkampf (1738-1815), who had emigrated to France in 1758 from Switzerland to meet the need for specialized textileprinting workers. The plant developed rapidly thanks to the quality of its products and the attention given to the creation of new designs. The

Aziza Gril-Mariotte is an Associate Researcher in the Department of Art History at the University of Aix-Marseille. 
beauty of the fabrics and their motifs ensured the reputation of the Jouy factory, which earned the title of Manufacture Royale in 1783.4 Oberkampf began copperplate printing in 1770, initially concentrating on floral patterns for clothing. At first, designs with figures made up only a small part of his products. ${ }^{5}$ Soon turning to fashionable themes and recent events in the monochromes, however, Oberkampf spread the reputation of his factory's products and assured its later fame: the reprinting of his designs in neo-Louis XVI interiors at the end of the nineteenth century would give rise to the eponymous term toile de Jouy for such cottons. ${ }^{6}$

The drawings and printed fabrics that have survived reveal how Oberkampf's designers adapted occurrences and fashions to textiles destined to decorate interiors. The interpretation of current events had to satisfy a wide public. This cultivated if not extremely wealthy clientele made its purchases in the boutiques of the Palais-Royal or in the shops of large provincial cities. The manufacturer chose the subjects represented, but also the right moment to print and promote them, because, as Oberkampf remarked:

One must be able to read into the future to know which type will supplant that which is already in place, because in every era, there is a type that is more sought after than the others and this will always be the case. The most skilled is also the man who knows when to stop in time in order to have the fewest leftovers when that type ceases to please.?

Oberkampf placed a great deal of emphasis on the creation of designs, which he himself originated until 1764, when he hired a designer. ${ }^{8}$ Thereafter he carefully supervised the design studio. Seeking to perfect the art of textile printing as much by the invention of new patterns as by new techniques and dyeing processes, Oberkampf also commissioned artists to create compositions that would build the reputation of the factory. After obtaining the title of Manufacture Royale in 1783, for example, he commissioned a design representing Les Travaux de la manufacture from Jean-Baptiste Huet (1745-1811), inaugurating a relationship that would not cease until the artist's death. Huet had entered the Royal Academy of Painting and Sculpture as an animal painter in 1769 , and then achieved a certain success in the pastoral genre. ${ }^{9}$ The factory archives reveal how the relationship between the producer and the artist was established. ${ }^{10}$ Numerous compositions for Oberkampf have been attributed to Huet, although study of drawings in the Cabinet des 
Dessins at the Musée des Arts Décoratifs in Paris reveals the possibility of the existence of other, mostly anonymous, hands. Were these drawings by other, lesser-known, less talented artists, or by students or collaborators of Huet's, or were they simply made by other designers employed by the factory?

Oberkampf's representations of current events were designed to attract the broadest possible audience, and yet they went out of fashion quickly and could even become impossible to sell, especially when the fabrics represented political events. The manufacturer was above all a producer. The creation of new designs was intended to "facilitate sales, on which the prosperity of the establishment depends,"11 and existing designs were speedily adapted to new fashions and tastes, above all before his competitors did. With this goal, Oberkampf used several procedures to recycle his creations and continue to print them as long as possible.

Toiles de Jouy have been the subject of two significant recent publications and have given rise to a number of exhibitions. ${ }^{12}$ In La Toile de Jouy (2003), Mélanie Riffel and Sophie Rouart assembled printed fabrics illustrating current political and scientific events in a subsection of their book headed "Oberkampf and His Times."13 Oberkampf's themes were not limited to such events, however, and he envisioned them in a broader fashion in the early nineteenth century. The study of drawings and the archives of the Jouy factory, as undertaken below, brings new elements to light that allow a reinterpretation of certain compositions, the establishment of precise dates for some designs, and a better understanding of the marketing of these textiles. Letters sent by Oberkampf to his correspondents highlight the fiscal and creative methods he used to improve the sale and distribution of textiles with current themes. They also provide information regarding the titles ${ }^{14}$ and the numbering of designs, ${ }^{15}$ allowing the retracing of the chronology of certain evolving printed compositions.

\section{Representing "Balloon Mania"}

When Oberkampf printed compositions related to sensational events, he echoed the accounts given in newspapers, gazettes, and especially in images. Engravings played an important role in the circulation of such stories, and designers appropriated their iconography in order to create stylish designs. For example, when the factory printed cotton fabrics with balloons, scholars have viewed this as an adaptation to the "balloon mania" provoked by French experiments with hot air balloons ("montgolfiers") between 1783 and 1787, when the main ex- 
periments with balloons took place. These public tests aroused the curiosity and enthusiasm of the crowds who came to see the first liftoffs. ${ }^{16}$ Numerous people attended, and announcements and descriptions published in newspapers and especially engravings informed people about these events.

"Balloon mania" developed in the visual arts and then spread to the decorative arts, from interior decoration to numerous fashionable objets d'arts of the late eighteenth century. Jacques A. C. Charles and NicolasLouis Robert's balloon and the Réveillon of the Montgolfier brothers Joseph-Michel and Jacques-Étienne became fashionable ornaments, which the manufacturers of printed textiles used in profusion. These balloons can be found in polychrome printing, as well as in monochrome upholstery. In polychrome fabrics, however, the balloons are simply a modish decoration, whereas in monochrome upholstery, large designs evoke the conquest of the skies. According to the archives, Oberkampf had at least three pieces of monochrome upholstery printed with balloon motifs, but only two are known today: Le Parc du château and Le Ballon de Gonesse. ${ }^{17}$

The first introduced, Le Parc du château (Fig. 1) represents the hydrogen balloon of Charles and Robert after its launching in the Tuileries Garden on December 1, 1783. In the absence of documentation, the composition and the style of the motifs permit an attribution of this design to Jean-Baptiste Huet. A decoration with Neoclassical arabesques integrates the garden scenes associated with the ascension of Charles and Robert, who are seen seated in the gondola under the balloon. The balloon is only one element in a garden scene suggesting the Tuileries, while the crowd depicted in many engravings about the adventure (Fig. 2) is reduced in the toile to a few people who doff their hats or point to the exploit. In this engraving the importance of the balloon seems limited, but the motif evokes the meaning of the story of Charles and Robert's ascension. Nor did the designer neglect the decorative possibilities, because little balloons appear to ornament the medallions, acanthus wreaths, and garlands in the textile (Fig. 1). The number of this design, D108, allows dating its creation to around 1784, during full "balloon mania." 18 A wallpaper version was also produced (by an unknown manufacturer, not by Oberkampf)), but its composition was very different because the manufacturer privileged the decorative elements to realize an arabesque design. The principal scenes, which were the main motifs of the figurative printed fabric, have disappeared. ${ }^{19}$ In contrast to other themes in printed textiles, compositions referring to 


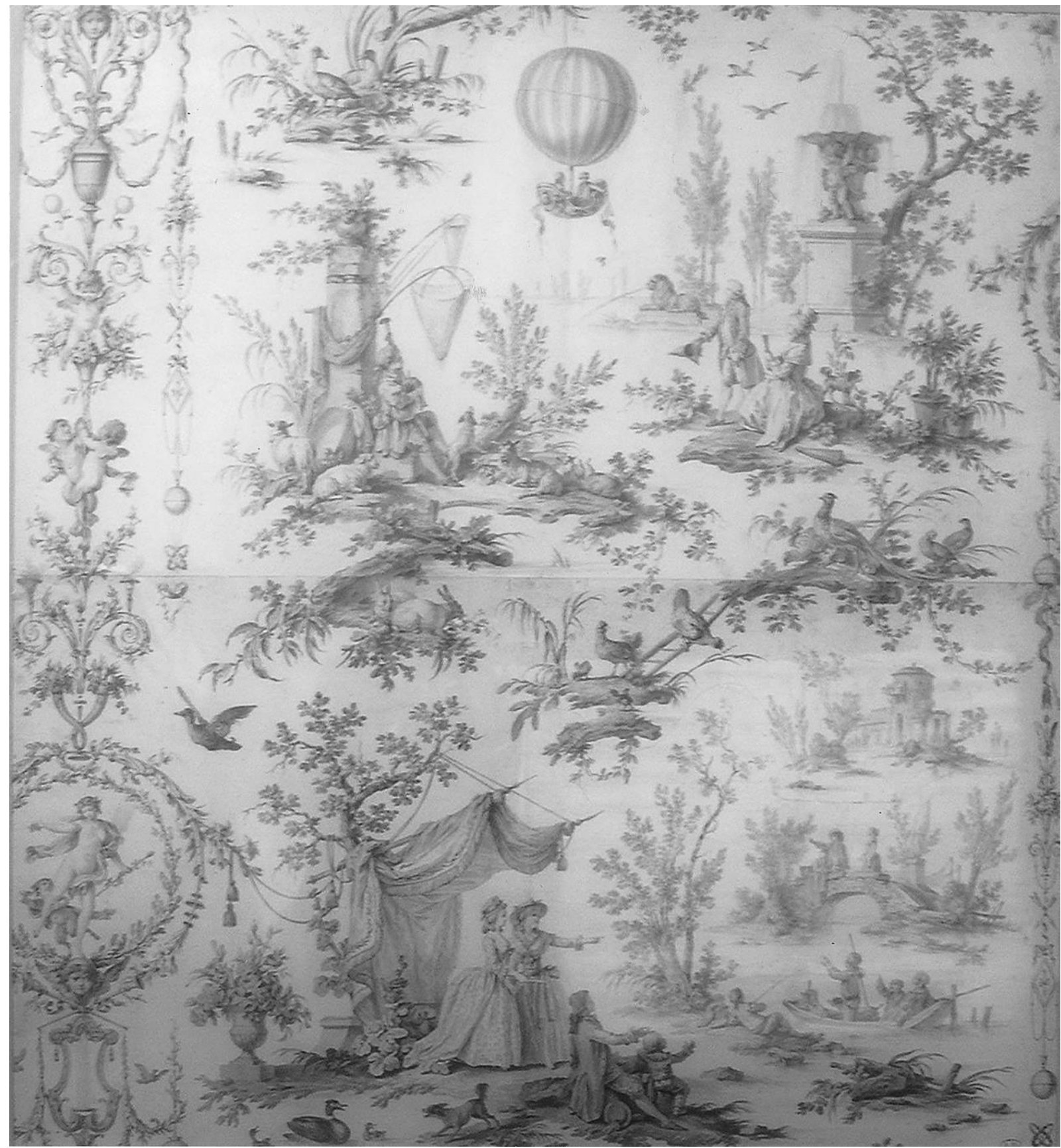

current events had to be chosen and executed rapidly because the engraving of the copperplate took much longer than a drawing and the printing of a fabric took at least two months in good weather, sometimes 


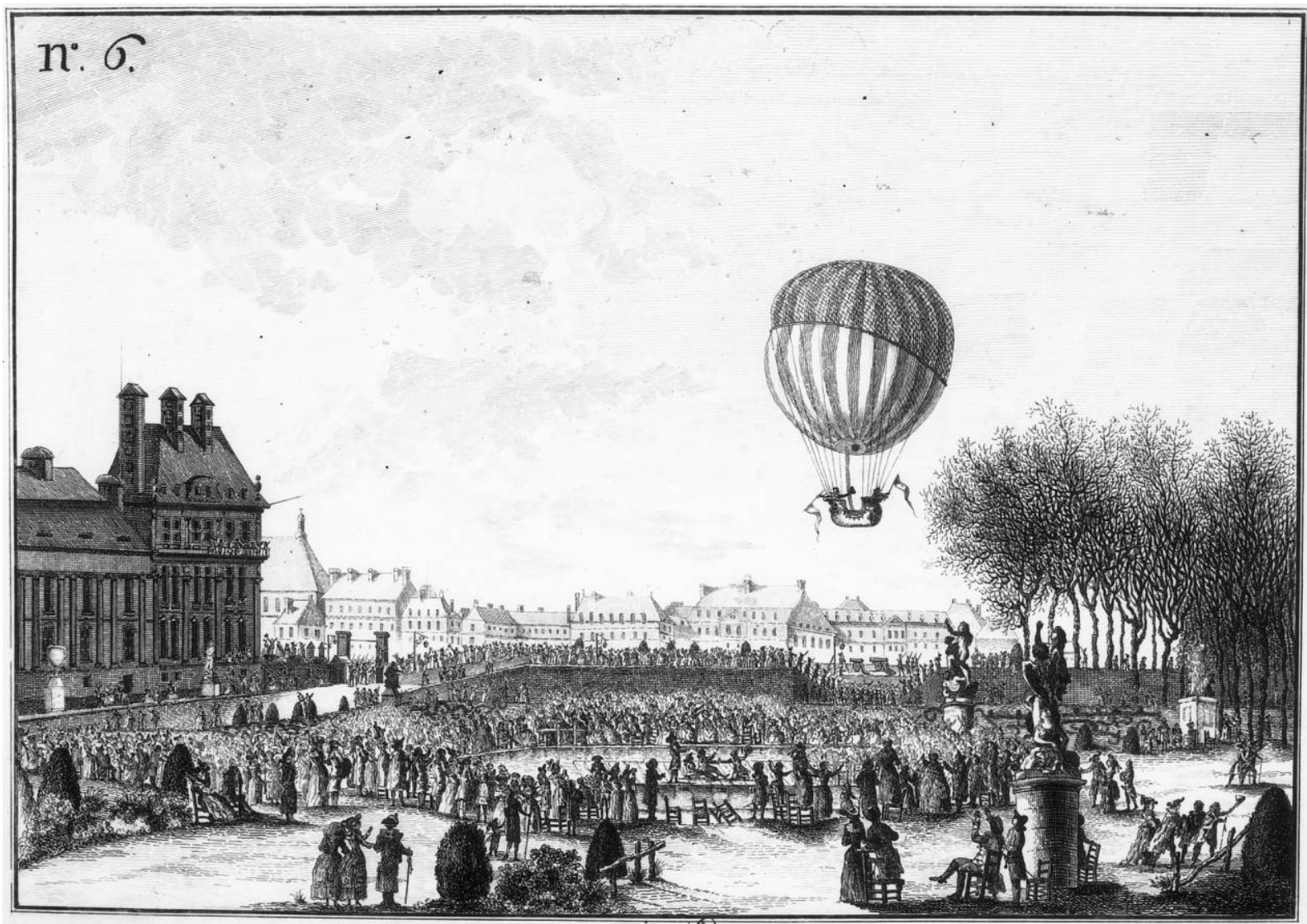

longer because it was necessary to bleach the cotton outdoors, in the fields.

The second fabric, Le Ballon de Gonesse, was made later (Fig. 3). The design is less refined and cannot be attributed to Jean-Baptiste Huet. The scene recalls Charles and Robert's experiments of 1783 and three incidents involving the balloon that year. On August 27, the balloon, departing from the Champ de Mars and arriving in the commune of Gonesse, was destroyed by a shotgun blast from the terrified residents of the village (Fig. 4); on December 1, Charles and Robert boarded the wicker basket and flew over the Tuileries Garden, seen in perspective (Fig. 6), and then arrived in the Nesles Prairie, near L'Îsle-Adam in the region of Paris (Fig. 5).

The designer borrowed his motifs from engravings that depicted Charles and Robert's adventure in their aerostatic balloon, from the first lift-off in the Tuileries to the first flight of the hydrogen-filled craft. These engravings responded to the curiosity and interest that such
FIGURE 1 (facing page)

Le Parc du château, attrib. to Jean-Baptiste Huet, 1785. Ink and gray wash on paper, 103.5 x $93.5 \mathrm{~cm}$. Musée des Arts

Décoratifs, Cabinet des Dessins, Paris.

Photo: author.

FIGURE 2

Alexandre-Louis-Robert Millin du Perreux, the Younger, Globe aérostatique de Mssrs Charles et Robert au moment de leur départ du jardin des Tuileries, le 1er décembre 1783, c. 1783-1784, engraving by LouisAlexandre Bouteloup. Bibliothèque Nationale de France, Département des Estampes et de la Photographie, Paris. 


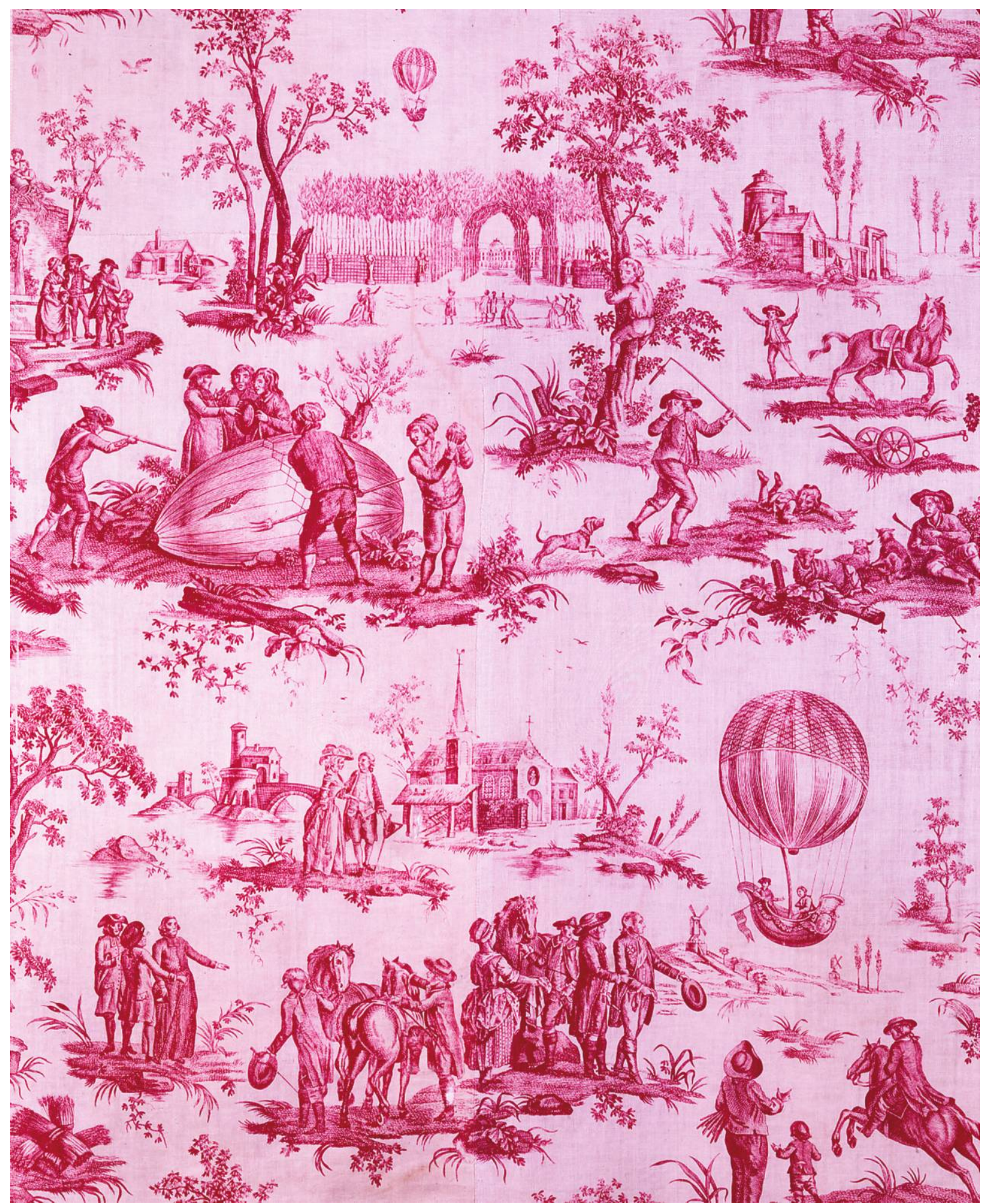


FIGURE 3 (facing page)

Le Ballon de Gonesse, 1790. Printed cotton, repeat 101 x $92.5 \mathrm{~cm}$. Musée de la Toile de Jouy, Jouy-en-Josas. Photo: Marc Walter.

\section{FIGURE 4}

Alarme générale des habitants de Gonesse, occasionnée par la chute du ballon aérostatique de $\mathrm{Mr}$ de Montgolfier, le 27 août 1783, c. 1783, engraving. Bibliothèque Nationale de France, Département des Estampes et de la Photographie, Paris.

\section{FIGURE 5}

Vue de la plaine de Nesle avec l'atterrissage du ballon aérostatique de MM. Charles et Robert, le 1er décembre 1783, c. 1783-1784, engraving. Bibliothèque Nationale de France, Département des Estampes et de la Photographie, Paris.
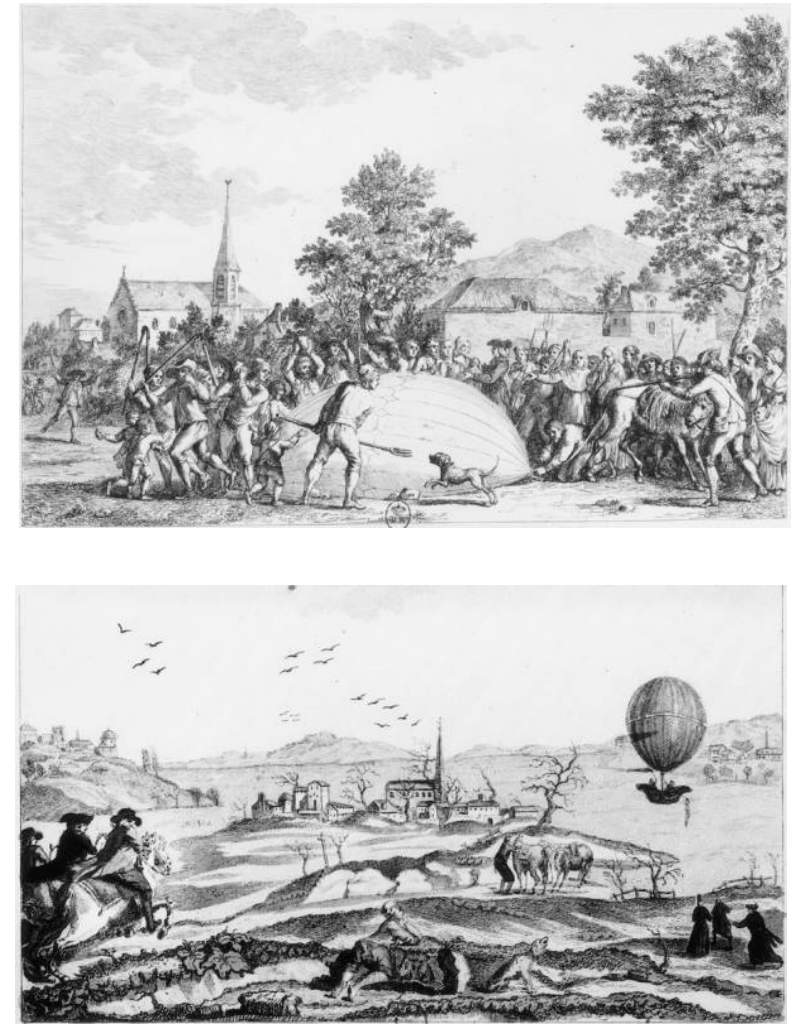

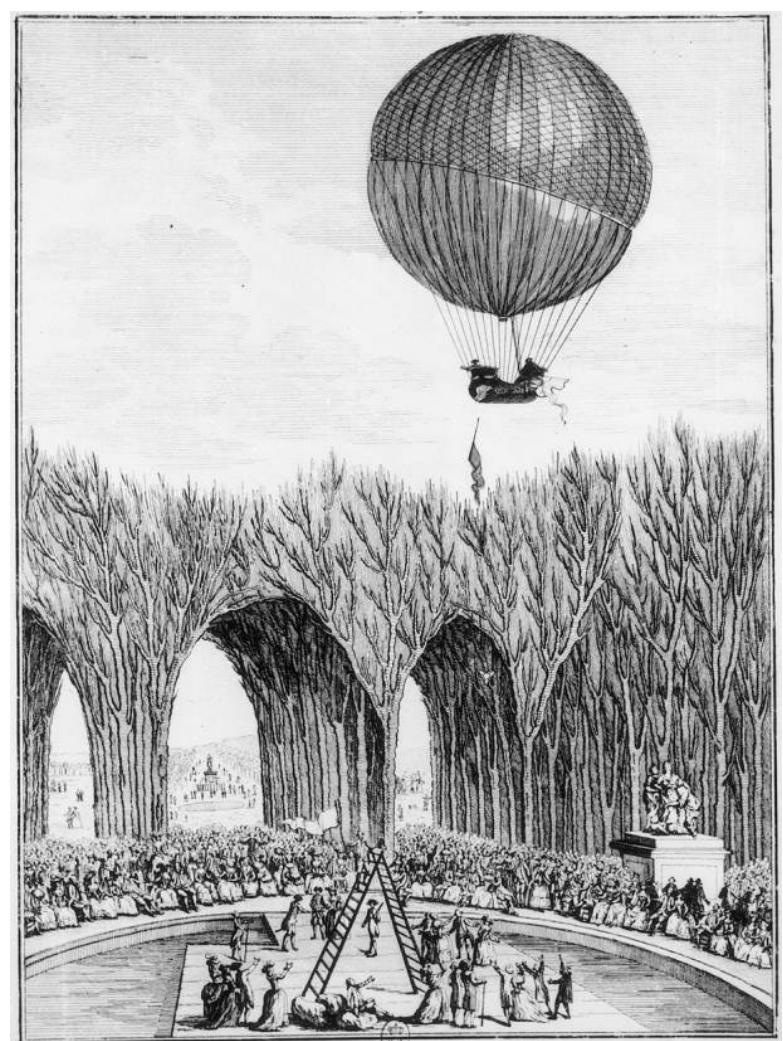

FIGURE 6

Elévation du globe aérostatique de MM. Charles et Robert au jardin des Tuileries, le ler décembre 1783, c. 1783-1784, engraving. Bibliothèque Nationale de France, Département des Estampes et de la Photographie, Paris. 
adventures aroused, and certain scenes such as the destruction of the balloon at Gonesse became renowned. Oberkampf also commissioned another version of the Ballon de Gonesse (Fig. 7) where the Réveillon of the Montgolfier brothers, on which the first human lift-off took place, replaces the perspective of the Tuileries Garden (Fig. 8). The designer gathered together the important events marking the ascensions of 1783 , but there is no evidence that this version was ever printed.

The style of these two designs recalls other productions, perhaps by a designer connected to the factory whom Oberkampf asked to execute a new design using balloons. His number D166 indicates a fairly late creation, around 1790, when public enthusiasm for these experiments was waning considerably and balloons were no longer fashionable attractions. The design might have been created at the request of a scientific circle or by balloon aficionados, because Oberkampf specifies to a merchant in November 1790 that he is making "plate number D166 of the Balloon of Goneze" only "on order." 20 By choosing to represent the events that marked balloon lift-offs, designers not only participated in the ambient "balloon mania" but also offered customers genuinely popular images, letting them recall the extraordinary spectacle of these first balloon flights, which were attended by huge crowds. ${ }^{21}$

\section{Current Political Events}

In order to avoid censorship, newspapers and gazettes, such as the Mercure galant, accorded a great deal of attention to literary and society events and to illustrated fashion chronicles, while newspapers controlled by those in power circulated bowdlerized political news of France and the other major European courts. The French thus learned of the signing of an alliance between France and the United States represented by Benjamin Franklin, plenipotentiary minister in Paris, on February 6, 1778. From the moment of the signing of this treaty between the newly independent states and France, engravings celebrated the event with symbolic images. ${ }^{22}$ Public attention was amplified when Louis XVI sent the Americans an expedition of six thousand men commanded by the marquis de Rochambeau and the marquis de La Fayette in 1780. Support for America against England was widespread among the French people, who followed news of the Revolution with enthusiasm. The War of Independence became an important source of inspiration for artists, as paintings, engravings, and numerous decorations dedicated to this history attest. 
Oberkampf, always eager to be the first to record sensational events, printed a design that is today called Hommage de l'Amérique à la France but was originally called Union de la France à l'Amérique (Fig. 9). The number of the design, D95, allows its date to be located around 1780. 1781, just after La Fayette and Rochambeau's departure for America, as the presence of the citadel of La Rochelle (bottom left) confirms. ${ }^{23}$ From a marketing standpoint, this composition was introduced at a moment when the French were paying more attention to the story because of their new military presence. The theme of the composition is the support of France for America during the War of Independence, with maritime scenes evoking trade relations and the departure of French soldiers. The main motif represents France as a mature woman wearing a crown, beneath a cloud bearing a figure of fame, and flanked by a vigorous charger and several well-armed soldiers welcoming the representatives of the American colonies, who have come to ask for her help. The newly

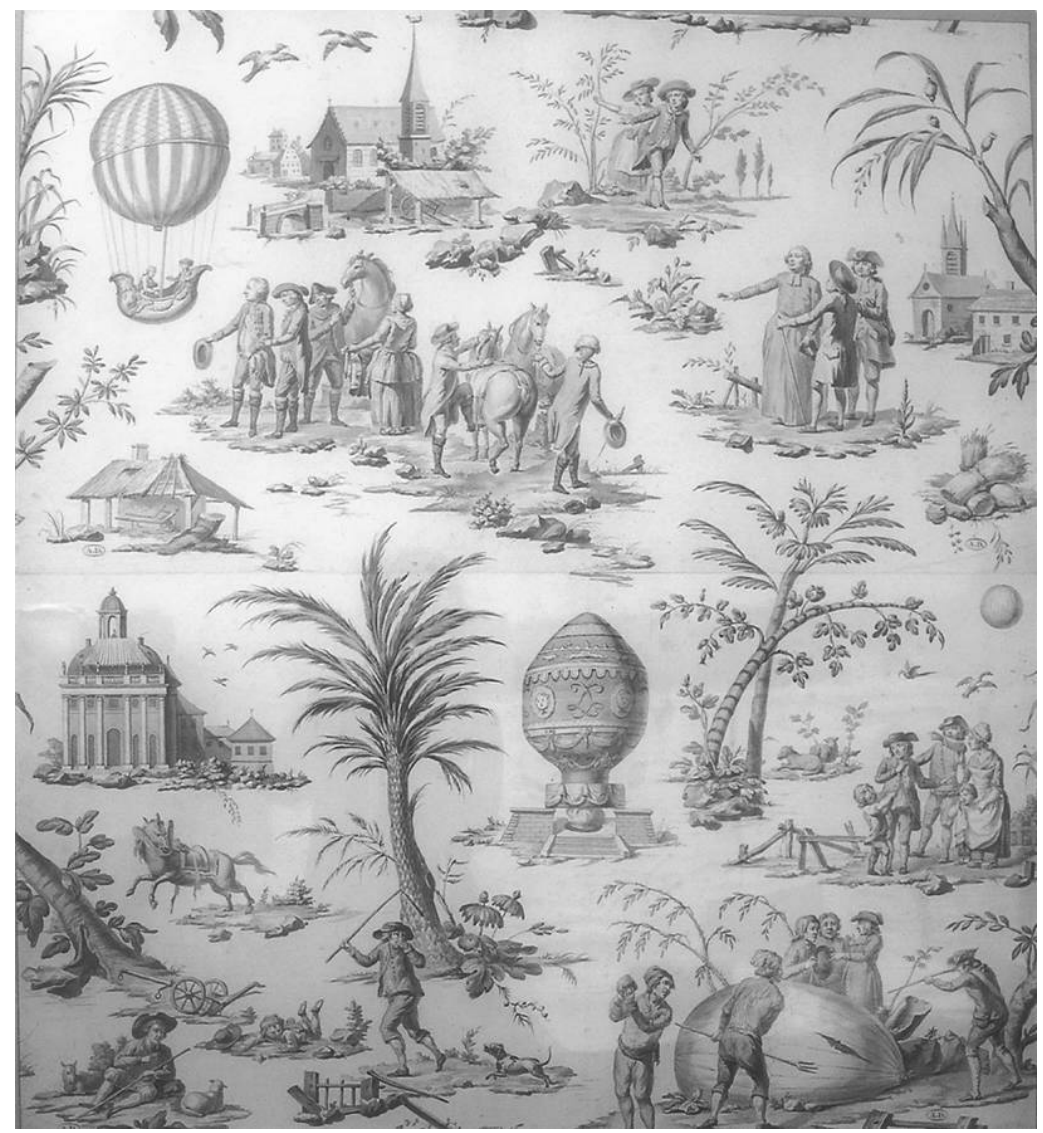

FIGURE 7

Le Ballon de Gonesse, drawing for the second, unprinted version, date unknown. Ink and gray wash on paper, $102 \times 92 \mathrm{~cm}$. Musée des Arts Décoratifs, Cabinet des Dessins, Paris. Photo: author.

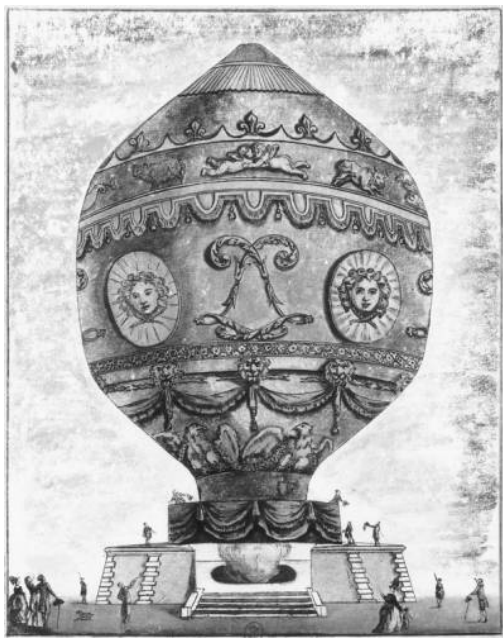

FIGURE 8

Elévation du Réveillon au Château de la Muette, le 11 novembre 1783, November 23, 1783, engraving. Bibliothèque Nationale de France, Département des Estampes et de la Photographie, Paris. 


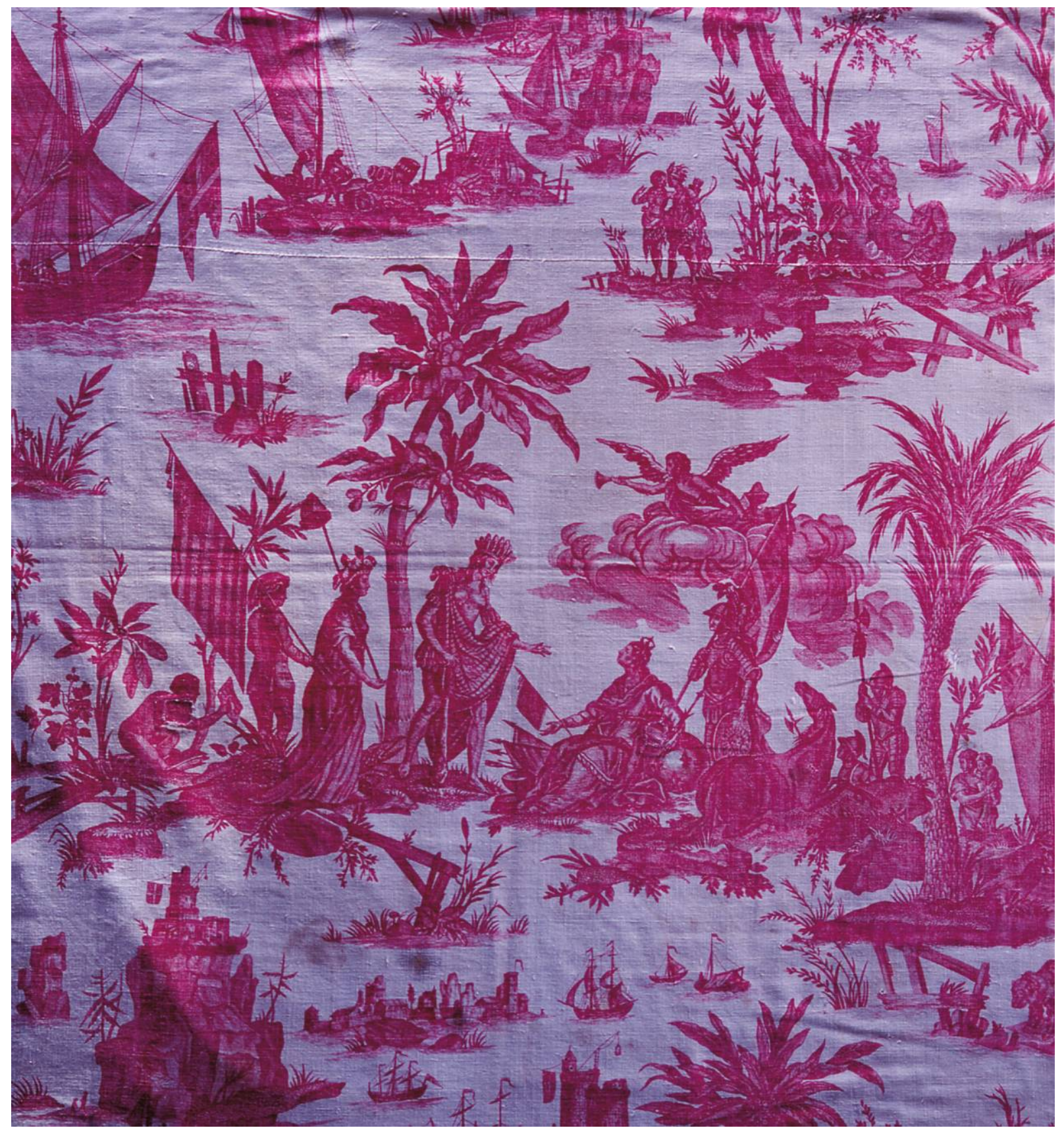

independent states appear in the form of a Native American woman, followed by Liberty carrying a Phrygian cap at the end of a spear, and a young man representing the Americans holding a flag with thirteen stars. 
Study of the original design affords an understanding of the principal scene better. ${ }^{24}$ This is not a scene of paying homage, as has always been thought, but rather an image that symbolizes the signature of the treaty in 1778 and the deployment of French troops in 1780. Engravings celebrating the event with similar compositions and the title L'Union de la France à l'Amérique found in the papers of the manufactory support this new interpretation. ${ }^{25}$ In fact, seminude and crowned America unites herself with France, while Liberty blesses this alliance. A kneeling black man brandishes the Declaration of the Rights of Man while, behind him (not visible in Fig. 9), an English soldier leaves in protest and another leans on a cane. In order to evoke the power and greatness of France, the designer borrowed from the allegory of Europe as it had been codified in iconological treatises and prescribed in academic training:

EUROPE. That part of the world that excels above all others, is represented to us by a woman royally dressed.... She wears a rich crown on her head.... A horse can be noted beside her, with a quantity of trophies and arms of all kinds... The crown that she wears shows that Europe has always had the principal advantage over other parts of the universe, over which she triumphs as queen.... The scepter that she holds is the symbol of power, because within her realm the most important princes of the world hold court.... By the horse and the arms that can be seen around her, it is evident that she has always won the prize in matters of noble knowledge and in exercises of war. ${ }^{26}$

On the other hand, in the design, the image of America departs somewhat from the usual codes in that she appears as a seminude Indian woman, with only a loincloth and a feathered headdress. This iconological error is rectified in the printed fabric because she is dressed in a striped cloth drapery, as she is described in the iconological treatises:

\begin{abstract}
AMERICA. This woman who has an olive cast to her skin ... and a veil of several colors that half-covers her body, represents America. In addition to a highly pleasing feathered wrap, artfully arranged, which renders her particularly recognizable with this bizarre ornament, she carries in one hand an arrow, in the other a bow, and a quiver at her side. To which one can add that she has on her head a garland of several strange feathers and at her feet a type of lizard somewhat resembling a crocodile. As before, [there is] a human head ripped from its body, and cut through by a spear. ${ }^{27}$
\end{abstract}

The feathered crown was preserved and the striped cloth drapery was added in the plate. The scene thus symbolizes the new states of America
FIGURE 9 (facing page)

Union de la France à l'Amérique, 1781. Ink and gray wash with white chalk and sepia on paper, 102.5 x $93 \mathrm{~cm}$. Musée des Arts Décoratifs, Cabinet des Dessins, Paris. Photo: author. 
in their youth and their strength, uniting themselves with France, an old nation, because of its renown, its wisdom, and especially its military power. The other motifs, the port, the citadel, and the merchant ships, allude to the trade relations established by the treaty of February 6, 1778, and to the departure of the French military. The theme of this composition is thus the alliance concluded between France and the United States of America.

The arrangement in the fabric in Figure 9 of motifs of different relative dimensions provides a bit of variety, alleviating the effect of repetition of the scenes, which in any case is not as obvious when the fabric is draped in folds. ${ }^{28}$ The games with scale highlight the central scene of the alliance, complemented by the other, smaller motifs. The success that this fabric enjoyed reflected the interest aroused in this event and in the American war with England. The theme evoking a people's aspirations to liberty was easily adapted to the revolutionary ideals of 1789 in France, such that Oberkampf could continue to sell this fabric until the first years of the nineteenth century. ${ }^{29}$ This design met with a certain success, as demonstrated by the Réveillon factory's production of a wallpaper based on it, and the motif printed in Jouy was crudely copied by a factory in Nantes. ${ }^{30}$ The events that marked the War of Independence were also opportunities for designers and engravers to make popular images. It was especially after the end of hostilities between France and England and the ratification of the treaty of Versailles by Louis XVI on September 3, 1783, however, that the American Revolution became a very popular artistic theme. Numerous engravings, paintings, and medallions celebrated the American victory and emphasized the role of France. With this design, Oberkampf thus managed to "read into the future," as he liked to say himself, to anticipate the fashion and tastes of his customers. ${ }^{31}$

After the signing of the treaty of Versailles, ${ }^{32}$ Oberkampf printed a second version, Liberté américaine (Fig. 10). The quality of this composition and the style of the motifs permit an attribution to Jean-Baptiste Huet. He mixes antique decoration, as seen in airy pastoral scenes evoking the Rousseau-esque taste for nature and country life, and refers to the War of Independence in two small medallions. The first (not visible in Fig. 10) is dedicated to Liberty represented as a profile wearing a Phrygian cap, accompanied by the inscription "Libertas Americana 4 juillet 1776," recalling the date of the Declaration of Independence, which marked the beginning of the war. In the second medallion, an allegory represents France with the traits of Minerva protecting America-shown as the child Hercules seated on a shield and strangling his 


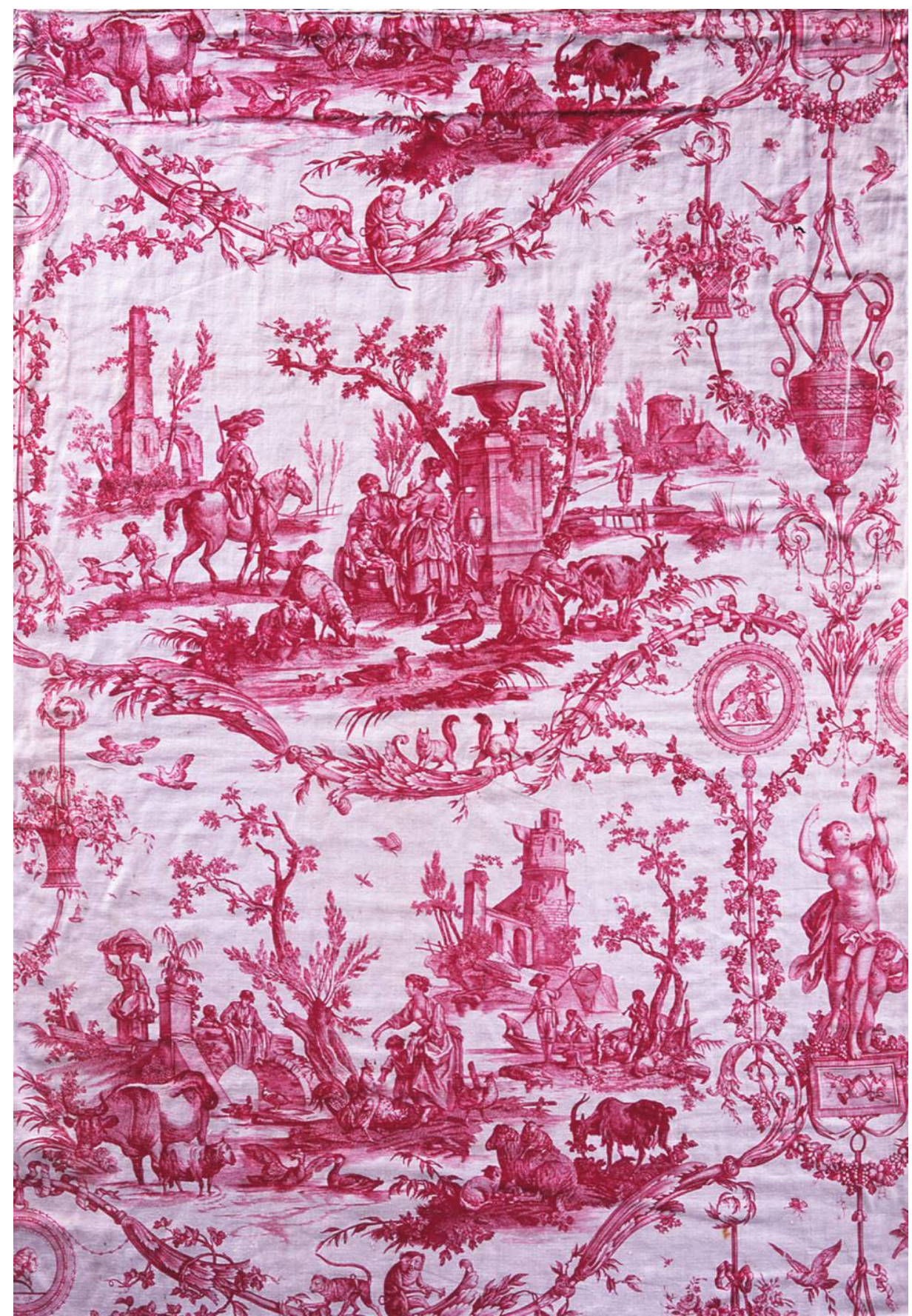

FIGURE 10

Liberté américaine, attrib. to Jean-Baptiste Huet, 1784. Printed cotton, repeat $101 \mathrm{x}$ $89 \mathrm{~cm}$. Musée de la Toile de Jouy. Photo: Marc Walter.

serpents-from the English leopard. Beneath (not visible in Fig. 10), the dates 1777 and October 17-19, 1781, refer to two major American victories over the British. On October 17, 1777, the Americans defeated 
General Burgoyne's troops at Saratoga, and on October 19, 1781, General Cornwallis's troops capitulated in Yorktown. ${ }^{33}$ Above the allegorical scene (not visible in Fig. 10) appears a citation in Latin from a poem by Horace: "Non Sine Diis Animosus Infans," meaning "with the aid of the gods, a courageous child." 34

These decorations are exact copies of the recto and verso of a medallion commissioned by Benjamin Franklin from the engraver Augustin Dupré in 1782 to celebrate the American victory over England. The idea for this allegorical group was Franklin's, who gave a precise description to the engraver. Dupré made a few changes and completed the medallion at the end of March 1783. ${ }^{35}$ At that time, the design was realized for Oberkampf and the engraving of the copperplate was undoubtedly begun. The manufacturer appears to have put the textile with this motif on sale beginning in $1784 .{ }^{36}$ Like the Union de la France à l'Amérique, this textile enjoyed a long success and the factory continued to sell it into the early nineteenth century. ${ }^{37}$

Jean-Baptiste Huet's works are typically known for their pastoral and animal scenes, as evident in Liberté américaine, but the Revolution let him take inspiration from current political events. Printed in 1789, his first composition had the theme of "Louis XVI, restaurateur de la liberté" (Fig. 11). Huet composed his designs using a vertical arrangement borrowed from the arabesque type, with a principal scene set off by a cartouche above and a medallion below, augmented on the sides by scenes of people drinking and dancing (not visible in Fig. 11), as well as by a representation of maritime commerce (not visible in Fig. 11). These images, as well as the allegory of agriculture in the cartouche, convey the message of a prosperous France. The only precise reference to current events is the depiction of the Bastille, seen in the medallion with a banner inscribed "la démolition de la Bastille 14 Juillet 1789." This motif appears as a detail in the composition, and yet the reference to the destruction of the prison, the symbol of monarchic despotism, evokes the new status of Louis XVI, who had become "king of the French," and actually wore the tricolor cockade on the citizen's tricorn, as does the youth with Mercury to the right here. This Louis XVI accepting reforms and responding to the aspirations of the people, however, contrasts with his representation as a Roman emperor.

The motif of the Bastille in the medallion was not borrowed from the numerous engravings illustrating the assault on it, but from a painting by Hubert Robert, La Bastille dans les premiers jours de sa démolition, shown at the Salon in September 1789. ${ }^{38}$ The painter presents a picturesque and dramatic vision of the event. The printed fabric, however, is not an 
illustration of the attack that launched the Revolution in July 14, 1789, but rather an allegorical composition of the political changes that the destruction of the Bastille represented.

Jean-Baptiste Huet's composition of La Fête de la Fédération, marking July 14, 1790 (Fig. 12), reflects an important event and his quick depiction of it, since Oberkampf paid 300 pounds in November 1790 "to Huet for the design of the Fédération." 39 The plate was then engraved and the textile was sold in the fall of 1791. In general, it took at least six months to engrave a copperplate and another two months to print the cotton, so the sale of fabrics portraying contemporary events began no less than the eight months after the event took place. ${ }^{40}$ For this cotton, Huet abandoned the arabesque composition, but organized his design once again around a central scene framed with a succession of natural motifs, playing on different scales to suggest depth. He chose an anecdotal representation where each protagonist is easily identifiable. Recognizable by his physiognomy, Louis XVI swears an oath to uphold the constitution and appears next to Liberty who brandishes a sword topped by a Phrygian cap. Both stand on a tribune topped with decoration $\grave{a}$ l'antique and an allegory of history framed by two white flags. National guards surround the tribune under the direction of La Fayette, with the queen and the dauphin on the left and the king's sister Madame Elisabeth and his daughter Madame Royale on the right. This anecdotal vision of the festival of the federation recalled the numerous popular illustrations that were produced, but the designer, out of a concern for legibility, limited the number of figures present. Huet simply evoked this immense festival uniting the French people by his depiction of the triumphal arch built on the Champ de Mars to commemorate July 14, 1789 , and by the scenes of dancing around the ruins of the Bastille (top left), as is specified in the sign attached to a tree: "Ici On Danse [Here We Dance]." Huet also gave an important place to the national guard (its recruiting, camps, and training), undoubtedly because he was a captain of the guard from Sèvres. ${ }^{41}$ His vision of the event is fairly close to that given by Hubert Robert in his painting Fête de la Fédération au Champ de Mars, 14 juillet 1790.42

In spite of subsequent revolutionary events, Oberkampf continued to sell this fabric until February 1795, when he ran out of his last pieces of the "Design ... of the Fédération." 43 It is impossible to identify the clientele who bought these two designs during the heat of the Revolution and the Terror, but there is no doubt that if merchants took the risk of buying them, it is because they were sure of being able to sell them or because they had specific orders. ${ }^{44}$ 


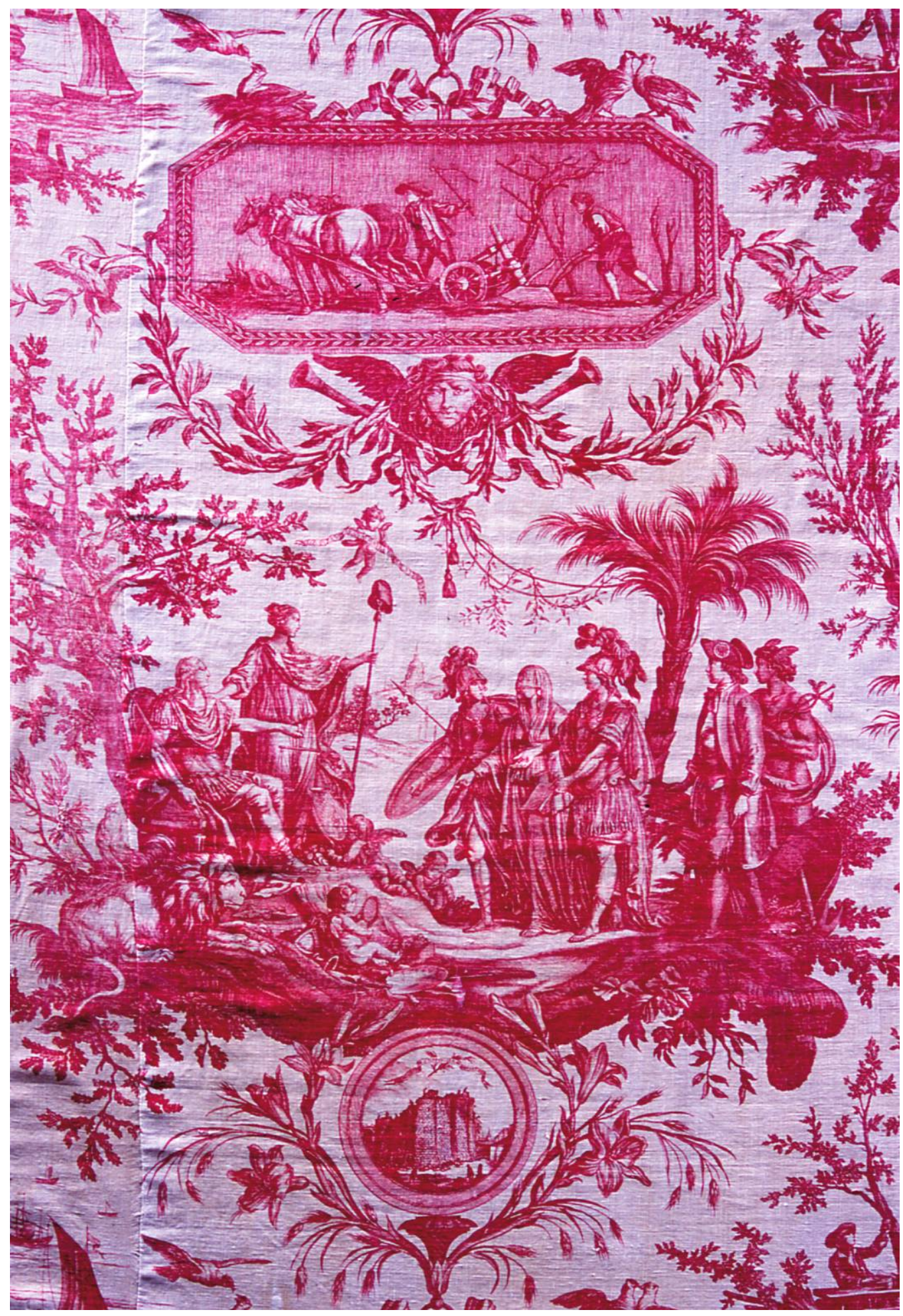




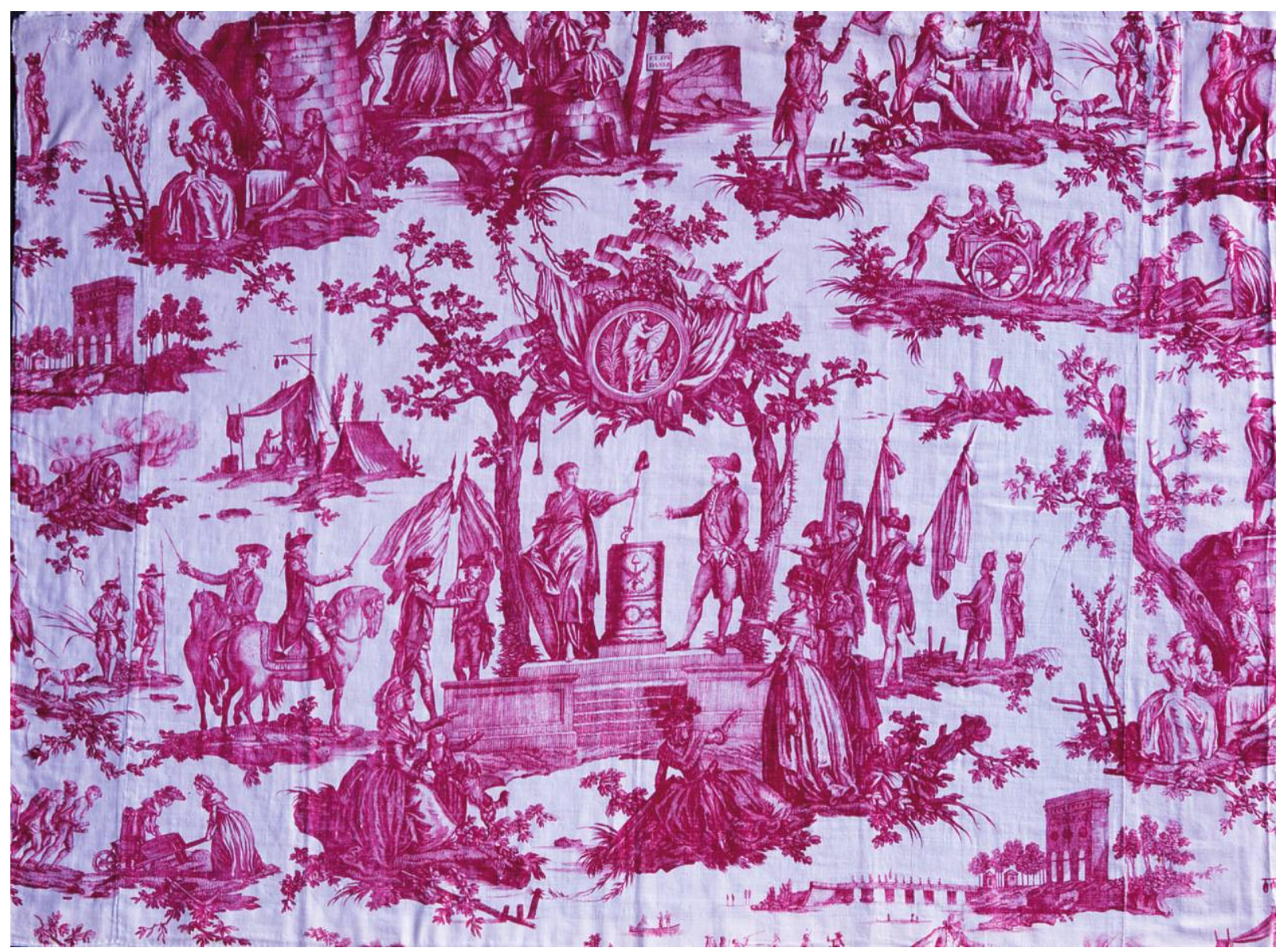

\section{Cultural Themes}

After producing these two designs, of "Louis XVI, restaurateur de la liberté" and "La Fête de la Fédération," the factory abandoned political subjects because the costs of the design and especially the engraving could be offset only if the design was printed for several years. ${ }^{45}$ Even during Napoleon's Empire, no Oberkampf fabric referred to the regime, nor did any present imperial emblems. Should this be taken as a reflection of Oberkampf's politics (although Napoleon awarded the factory the Legion of Honor in 1806), or merely his prudent attitude after the expense engendered by the two political designs, whose printing was relatively shortlived? The absence of references to Napoleon and to the Empire may also be explained by the personality of Jean-Baptiste Huet, who created most of the monochrome upholstery during this period. ( $\mathrm{He}$ was an artist of the ancien régime, whose paintings were in the taste of the
FIGURE 11 (facing page)

Louis XVI, restaurateur de la liberté, 1789.

Printed cotton, repeat 101 x $92 \mathrm{~cm}$. Musée de la Toile de Jouy. Photo: Marc Walter.

FIGURE 12

La Fête de la Fédération, 1791 (design by Jean-Baptiste Huet, 1790). Printed cotton, repeat 94 x $95 \mathrm{~cm}$. Musée de la Toile de Jouy. Photo: Marc Walter. 
eighteenth century, not the taste that developed during the First Empire.)

The factory did not completely abandon current events in the printing of its textile designs, however, because political events were replaced by cultural ones. Once again, the designers adapted fashionable themes current throughout the decorative arts. By calling on Huet's talent and speed of excution, Oberkampf could print innovative themes in the decorative arts before the manufacturers of other figurative printed fabrics. In 1803, Huet created a design inspired by Paul et Virginie (Fig. 13), when the novel by Bernardin de Saint-Pierre enjoyed an especially large following. ${ }^{46}$ The success of the novel was reflected in both painting and engraving, but also in all of the decorative arts. With its design, the Jouy factory offered customers a depiction of a fashionable theme already widespread in the arts. ${ }^{47}$ Huet took his inspiration from the engravings that accompanied the edition of 1789: the storm scene by Jean-Michel Moreau le Jeune, where Virginie lifts her overskirt to enwrap Paul (Fig. 14), and that of the shipwreck by Joseph Vernet (Fig. 15), engraved after the painting he exhibited at the Salon of 1789 , Le Naufrage de Virginie à l'île de France. ${ }^{48}$ The partial or complete copying of engravings to create motifs in the decorative arts was in fact widespread, and certain technical similarities between engraving and the printing of cotton from copperplates greatly facilitated the adaptation of engraved sources, as long as the designer simplified the motifs. By duplicating the engravings from the novel, the designer drew customers' attention to themes that would remind them of their reading. The illustrations printed on cotton did not substitute for those of the novel, but in choosing the story's four main episodes (Paul and Virginie's childhood, their happy life in nature, the departure of Virginie for France, and her shipwreck and death), it summarized the story in images.

Always committed to creating designs for the manufactory that closely followed recent cultural events, Jean-Baptiste Huet also composed Les Monuments d'Égypte, designated in the sources as meuble égyptien ou dessin égyptien (Fig. 16). With this design, for which "the engraver just recently finished the plate" in August 1807,49 the designer exploited "Egyptomania," a widespread phenomenon in the decorative arts following the return of Napoleon Bonaparte's expedition in 1801.50 The fabric fairly closely reflects current knowledge about Egypt following this expedition, and combines monuments from different periods: the fort of Qaï Bey with the port of Alexandria, the so-called Cleopatra obelisk after paintings by Louis-François Cassas engraved in the work of 

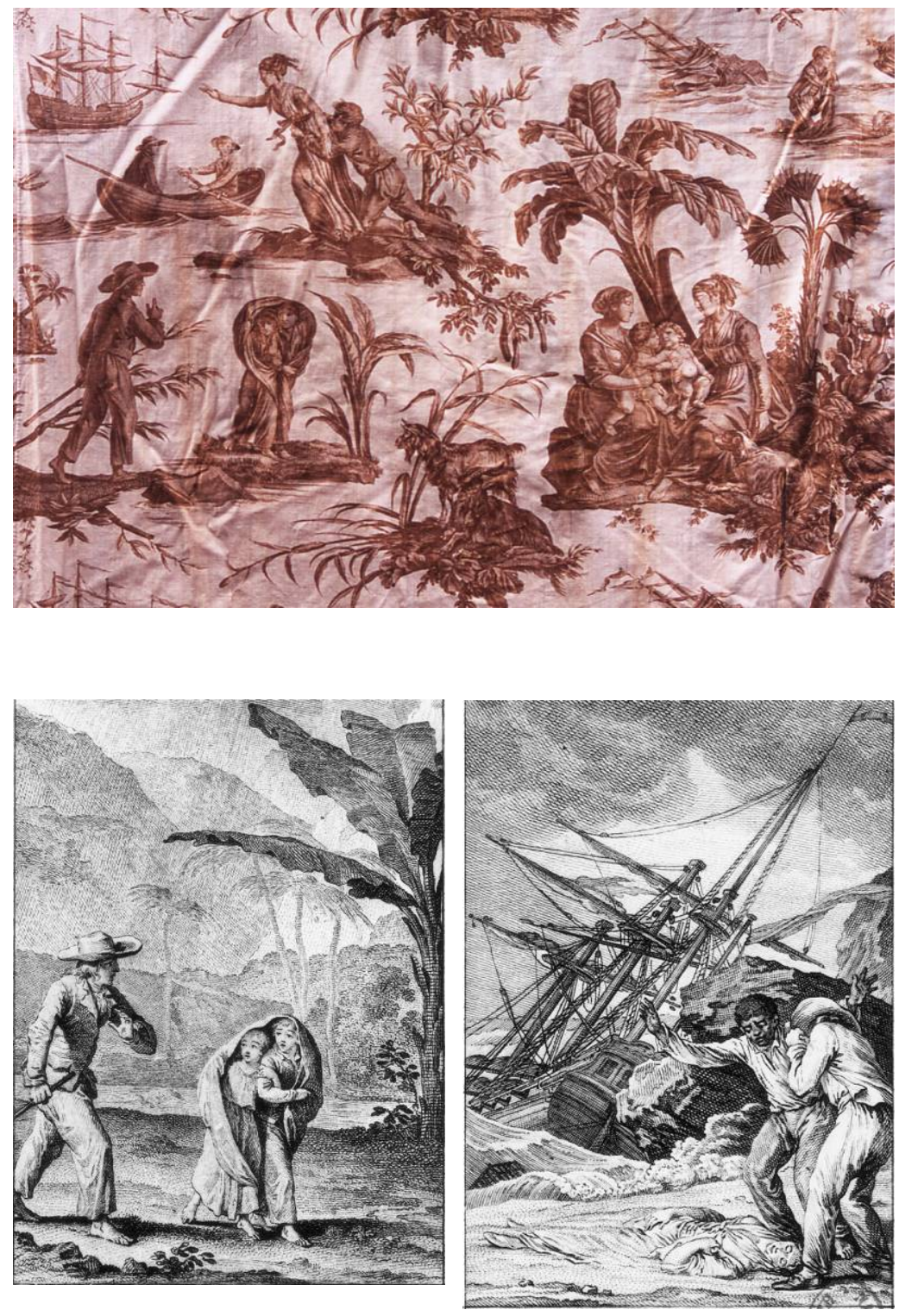

Dominique-Vivant Denon (1745-1825), ${ }^{51}$ and entrances to pharaonic temples, then believed to be tombs. Huet limited the picturesque aspects of the landscape to the scenes taken from the painter Cassas in order to emphasize decorative elements, which he arranged in a rigorously symmetrical composition on a background with a network suggesting the stonework of the pyramids. The theme of the composition is not Napoleon's expedition to Egypt, but rather Egypt itself.

\section{FIGURE 13}

Paul et Virginie, 1803 (design by JeanBaptiste Huet). Printed cotton, repeat 50.5 x $96 \mathrm{~cm}$. Musée de la Toile de Jouy. Photo: Marc Walter.

FIGURE 14

Paul et Virginie sous l'orage, after JeanMichel Moreau le Jeune, from novel by Bernardin de Saint-Pierre, Paul et Virginie avec figures (Paris, 1789), pl. 1. Photo: Bibliothèque Nationale de France, Paris.

FIGURE 15

Naufrage du vaisseau le Saint Géran et mort de Virginie. After Joseph Vernet, from novel by Bernardin de Saint-Pierre, Paul et Virginie avec figures, pl. 4. Photo:

Bibliothèque Nationale de France, Paris. 


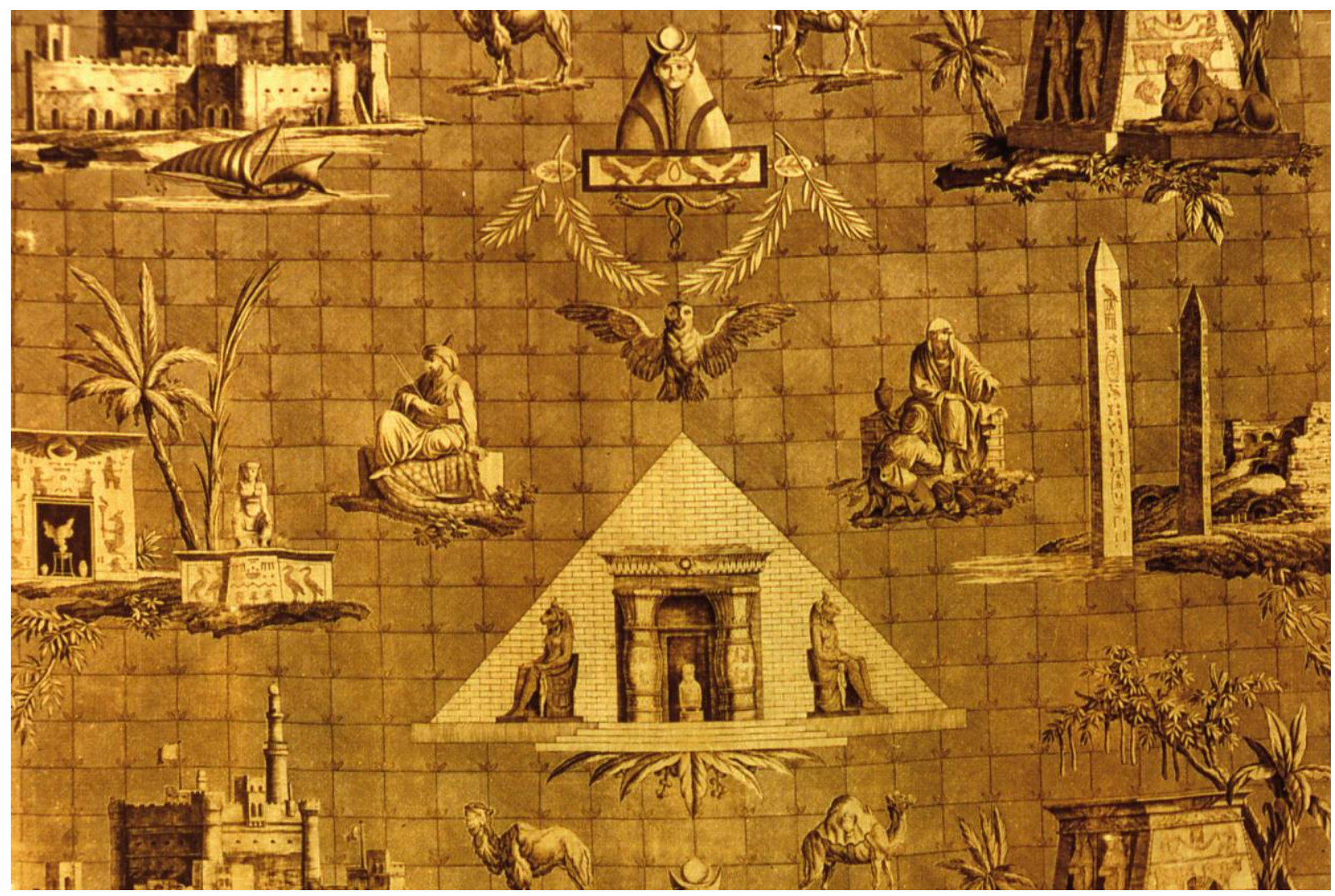

FIGURE 16

Meuble égyptien ou dessin égyptien, attrib. to Jean-Baptiste Huet, 1807. Printed cotton, repeat 52 x $95 \mathrm{~cm}$. Musée de la Toile de Jouy. Photo: Marc Walter.

FIGURE 17 (facing page)

Tancrède et Herminie, attrib. to Jean-

Baptiste Huet, 1809. Printed cotton, repeat 52 x $94 \mathrm{~cm}$. Musée de la Toile de Jouy.

Photo: Marc Walter.
The attention that Jean-Baptiste Huet paid to fashionable themes was also evident in his design Tancrède et Herminie, inspired by Tasso's epic poem Jerusalem Liberated (Fig. 17). The design was engraved starting in 1808, and in September, Oberkampf announced to his merchants that the engraving of his "new upholstery design Tancrède and Herminie" was not yet finished, but that he could deliver the first bolts to them the following spring. ${ }^{52}$ Huet did not chose this literary theme by chance. In fact, in the 1800s, Jerusalem Liberated constituted a privileged source for artists who translated the literary taste for the Middle Ages into the arts. ${ }^{53}$ Already in the eighteenth century, several musical works found their source of inspiration there, notably Christoph Willibald Gluck's L'Armide, an opera created in 1777 , which was subject to several revivals beginning in $1805 . .^{54}$ The literary work itself had several new editions: that published by Bossange and Masson in Paris had four large print runs between 1794 and 1811, proof of the success that Jerusalem Liberated enjoyed.

To stage this literary scene and to appeal to the taste for the Middle 


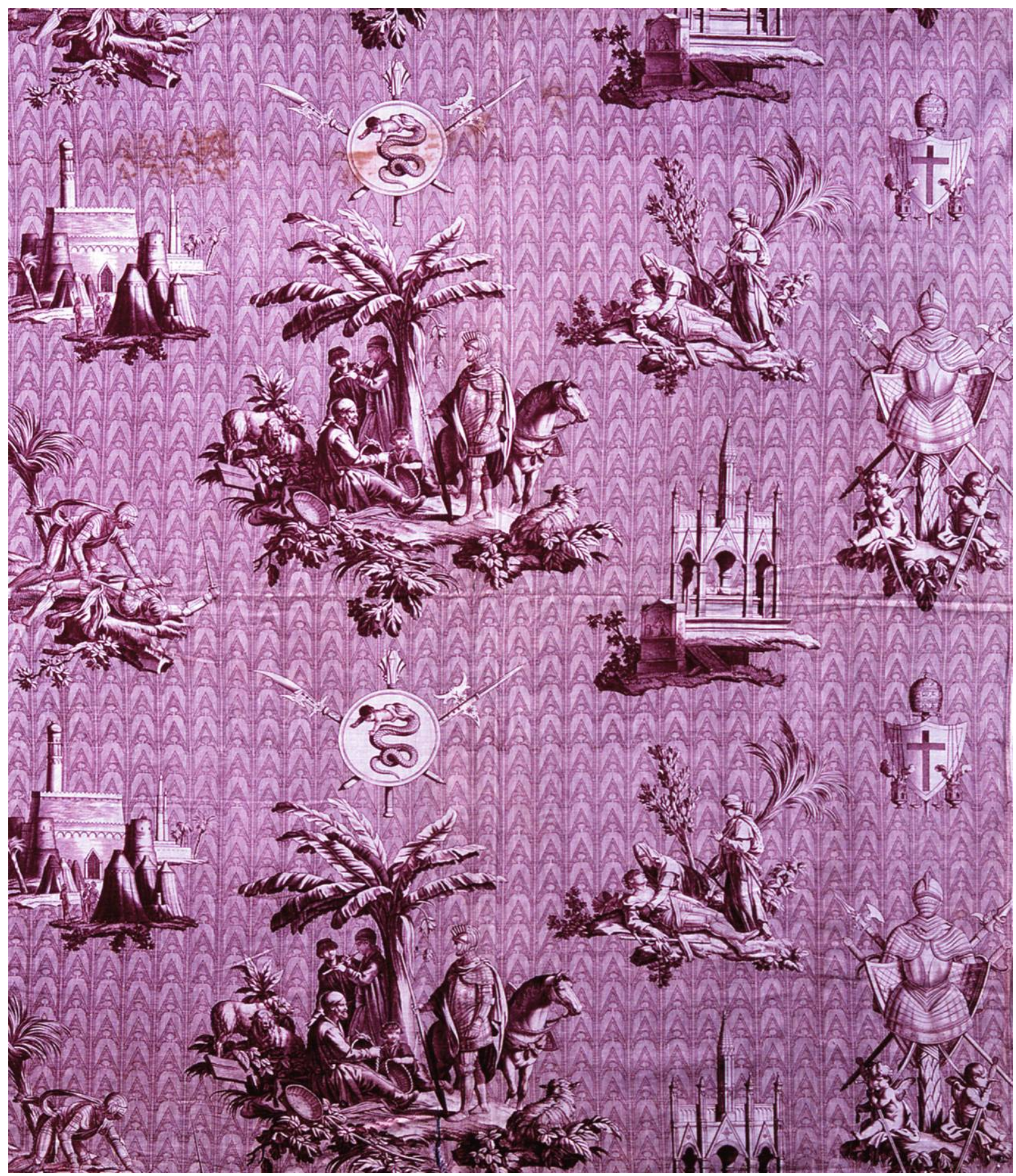


Ages, Huet composed his design in a rigorous fashion, arranging the motifs in a decorative conception fairly close to that of his Egyptian design, with an important scene in the center surrounded by other motifs. The Middle Ages is conjured up through a repertoire of decorative forms, such as the pointed arch in the background motif and the warrior's trophies. At the same time, customers can identify the intrigue between Tancrède and Herminie specified in the title of the textile. In the center, Huet chose the scene of ode VII, when Herminie, clothed in Clorinde's armor, looks for Tancrède in the camps of the Crusaders, there meeting a shepherd who invites her to share his pastoral life. This moment is not essential to the story, but it puts the heroine in action in a pastoral scene, a decorative opportunity the artist cherished. The tragic love story is represented by two scenes from ode XIX. On one side is the battle between Tancrède and Argant, when in verse XXVI, "he plunged and replunged his sword into his helmet," and on the other side appears the scene that ends the ode when Herminie, with her groom Vafrin, discovers the wounded Tancrède and believes him to be dead. Huet added several monuments: the fortress of Jerusalem with the Crusaders' camp and a Gothic funerary monument that situates the figures in time and place. Apart from the choice of a story exploiting the fashion for the Middle Ages, he organized his design in a composition that is above all decorative. Indeed, the interpretation of Jerusalem Liberated through the story of Tancrède and Herminie was in the end only a pretext for offering customers a fabric with a stylish and topical theme. In contrast to the design inspired by the novel Paul et Virginie, Huet did not use as sources Jean-Michel Moreau le Jeune or Charles-Nicolas Cochin's engravings, which illustrated several French and Italian editions of Tasso's epic poem (and do not in the least resemble Huet's design). .55

Oberkampf demonstrated a sharp perspicacity in his choice of literary successes for illustration, because themes such as Paul et Virginie or Jerusalem Liberated would endure iconographically for some time. ${ }^{56}$ The revival at several factories of the monochromes in the beginning of the nineteenth century was also marked by compositions where cultural events took the place of political ones. By emphasizing these modish themes, Oberkampf guaranteed the success of his products, which no longer risked going quickly out of fashion, even as the economic context grew particularly unfavorable for the industry of printed fabrics. (This was because of the Continental blockade from 1806 until the end of Napoleon's reign, which banned imports from England and also made it difficult to import raw materials because of a great increase in prices.) 


\section{Innovations in Marketing and Pricing}

At the beginning of the nineteenth century, Oberkampf took advantage of innovations in the marketing and sale of new designs. His textiles would see variations in pricing according to their newness, whereas before only the quality could justify such differences. Older designs on ordinary cotton were sold at 4.50 francs per length, "but these are not such distinguished designs"; newer designs on fine cotton were priced at 5.50 francs per length and the most recent at 6.50.57 Oberkampf always justified price differences for the same design by the quality of the cotton, but the new designs were only printed on the finest fabrics. In reality, Oberkampf saved the most beautiful cotton for the new designs, requiring merchants who wanted these nouveautés to pay the highest price. This process put the new designs at an advantage with a clientele that would not hesitate to pay a high price for the latest arrival. For this reason, Parisian merchants were often the first to sell the new designs, as well as the leading merchants in large provincial cities.

Oberkampf next offered designs that were already familiar in different qualities of cotton to satisfy the largest number of customers. He sometimes went even further in the manipulation of his market, and when he produced a new design, he often made the others unavailable. Thus in 1809, he answered a customer who regularly ordered monochrome upholstery: "I can only offer you one design: Tancrède et Herminie, a subject taken from Jerusalem Liberated. It is on fine cotton at the price of 7.00 francs per length." 58 Oberkampf did not seem to be in a hurry to reprint his other monochrome upholstery: by the following year, he still did not have any others:

The Tancrède et Herminie upholstery about which you inquired is one of my newest designs. I sell it at 7.00 francs per length and it is printed on superfine quality. I have a good number of other designs but they are out of stock at the moment. I will have them available for you for next summer. The prices will be lower than this and will vary according to the quality of the cotton..$^{59}$

In order to meet the demand for upholstery with human figures, merchants had no choice but to procure this design at Oberkampf's high price or to wait for the reprinting of others.

Oberkampf's correspondance cites the prices of different printed scenes, but it says nothing about the clients willing to buy such fabrics. It is generally believed that fabrics with human figures, which make up only a small portion of printed textiles, solidified the brand image of the 
FIGURE 18 (facing page) Jean-Baptiste Huet, Louis XVI, protecteur de la religion, 1788. Ink and gray wash on paper, 102.5 x $92.5 \mathrm{~cm}$. Musée des Arts Décoratifs, Cabinet des Dessins, Paris. Photo: author. factory with a wealthy clientele. ${ }^{60}$ The study of Oberkampf's entire production and pricing, however, gives a slightly different picture of their place. The number of monochrome figurative designs is tiny compared to that of polychromed impressions, but Oberkampf printed them in large quantities for his own account and for those of other merchants. ${ }^{61}$ The monochrome upholsteries were in the end common products because their median price corresponded to the lowest prices for polychromed upholstery, which were printed on cotton from India. The monochromes remained common consumer products, whereas the beautiful polychromed upholsteries were luxury items. Nevertheless, the monochromes were also offered at variable prices according to the beauty of the cloth and the printing in order to satisfy a diversified clientele. Oberkampf, by proposing new designs on fine cotton fabrics, met the taste of customers informed about the latest trends, while at the same time, he facilitated their diffusion into the more popular layers of society when he offered them at lower prices or printed them on someone else's behalf.

\section{The Recycling of Printed Designs}

Before abandoning representation of important events in the early nineteenth century, Oberkampf employed several techniques to adapt his compositions to shifting occurrences. Certain designs sometimes underwent significant transformation even before being engraved, while others were slightly modified. Sometimes a simple change in the title of a fabric allowed its continued sale. Oberkampf did not merely adjust the proportions and the details of a design before engraving it, but he intervened throughout the production process in order to adapt the designs to customers' interests and to reflect current events as closely as possible.

As indicated above, the production of printed fabrics referring to current events was in fact risky because the design could go out of date even before being printed on cloth: indeed, because it could take at least a year, often more, from delivery of the design to its commercialization in printed cloth. This was the case with Louis XVI, restaurateur de la liberté (Fig. 11). A comparison of the design titled Louis XVI, protecteur de la religion (Fig. 18) and the version printed on cloth with a slightly different title in Figure 11 reveals significant differences in the representation of the theme. The overall composition and the motifs are basically identical, but in the design Louis XVI as a Roman emperor accompanied by Justice does not welcome Liberty, but Religion, recognizable by the crucifix in her left hand, who is protected on either side by Mars and Minerva. The design is no less topical than the printed textile, however: 


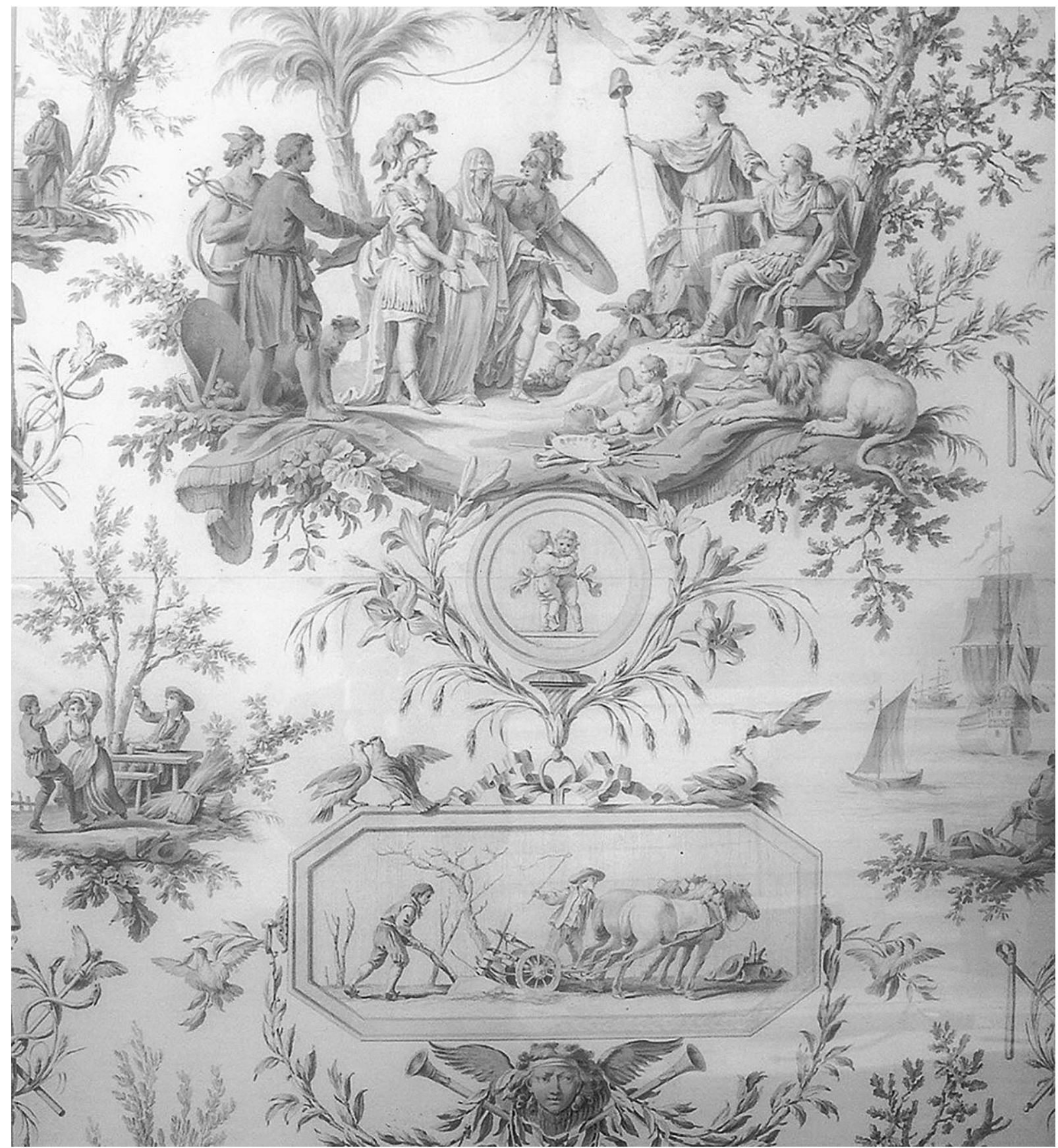

Huet's representation of Louis XVI as a protector of religious freedom was inspired by the royal promulgation in 1787 of an edict of tolerance that gave civil status to Protestants and permitted their worship. The lance 
FIGURE 19 (facing page)

Le Parc du château, attrib. to Jean-Baptiste Huet, 1790. Printed cotton, repeat $100 \mathrm{x}$ $93 \mathrm{~cm}$. Musée de la Toile de Jouy. Photo: Marc Walter. topped with a Phrygian cap present in the design symbolizes the freedom that this measure granted to Protestants. The theme of the design (done in 1788) was thus the inauguration of the edict of tolerance, which benefited the Protestant Oberkampf and his family, but the revolutionary events of July 1789 would make it out of date.

Oberkampf, having not yet completely engraved the copperplate, transformed several important details in the design and the fabric became an allegory of freedom. In the fabric, the banner held by a cupid above the king specifies the theme of "Louis XVI, restaurateur de la liberté"; the design's figure of Religion appears in the fabric without her crucifix (thus the veiled figure minimally transformed by the mere omission of the crucifix is awkwardly recast as Liberty, to economize by updating a design representing another theme to a more current one), while the cupids that decorated the round medallion were replaced by the destruction of the Bastille after Vernet and a banner on which is written: "Démolition de la Bastille 14 juillet 1789" above the building. The symbols evoking French royalty were all retained: the oak tree, the fleurs-de-lys, as well as the allegory of the arts at the king's feet, the lion symbolizing strength, and the cock symbolizing France. These transformations, including that of the title from Louis XVI, protecteur de la religion to Louis XVI, restaurateur de la liberté, reframed the design in the context of current events. Because Oberkampf saw it as still too linked to the personality of Louis XVI, however, it was changed again. In June 1790, he announced to a merchant in Nantes: "The design No. 140 is called the design of the Revolution, I beg of you to sell it under this name"; ${ }^{2}$ whereas certain shopkeepers also called it the "Demolition of the Bastille," reusing the inscription on the medallion. ${ }^{63}$ The modification of the title, in spite of the representation of Louis XVI, was an attempt to prolong sales of the design, and it succeeded. In March 1793, Oberkampf wrote: "I have only a few remaining of the design of the federation and the revolution and I am still selling them at the same price as the other pieces of upholstery." ${ }^{4}$ The beginning of the Reign of Terror nonetheless obliged him to sell off his last pieces of the design of the Revolution, at three pounds less per length. ${ }^{65}$ This was not the first time that Oberkampf modified a design before or after its engraving in order to adapt it to changing current events, but in this example, the subject of the composition was completely transformed.

Revolutionary events also explain the change in title of L'Union de la France à l'Amérique, which was called after 1790 La Révolution d'Amérique. In spite of this change, Oberkampf also had to sell the design 


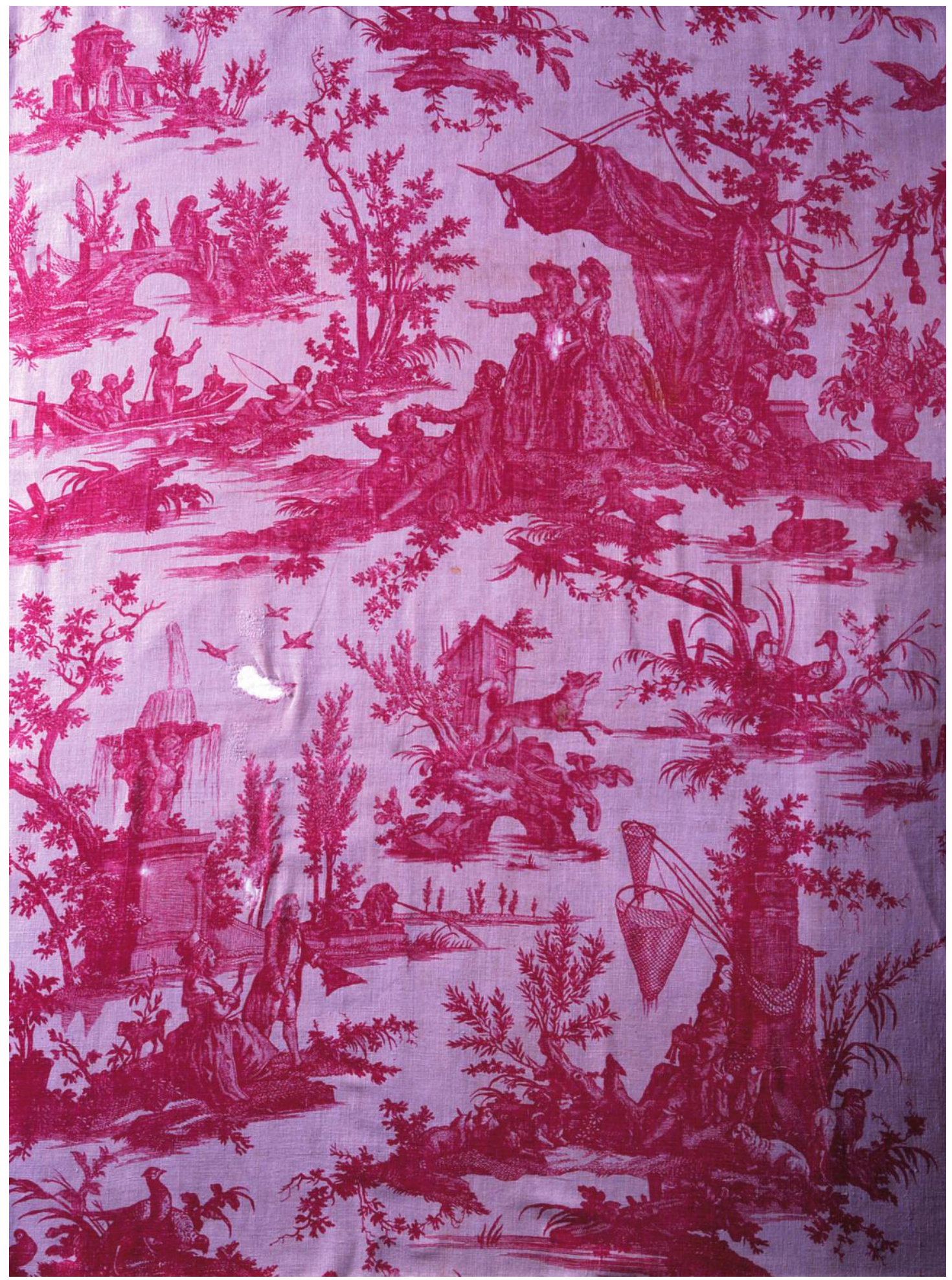




\section{FIGURE 20}

Untitled anonymous drawing, 1778.

Graphite with pink and white gouache, 104 x 93.5 cm. Musée des Arts Décoratifs, Cabinet des Dessins, Paris. Photo: author.

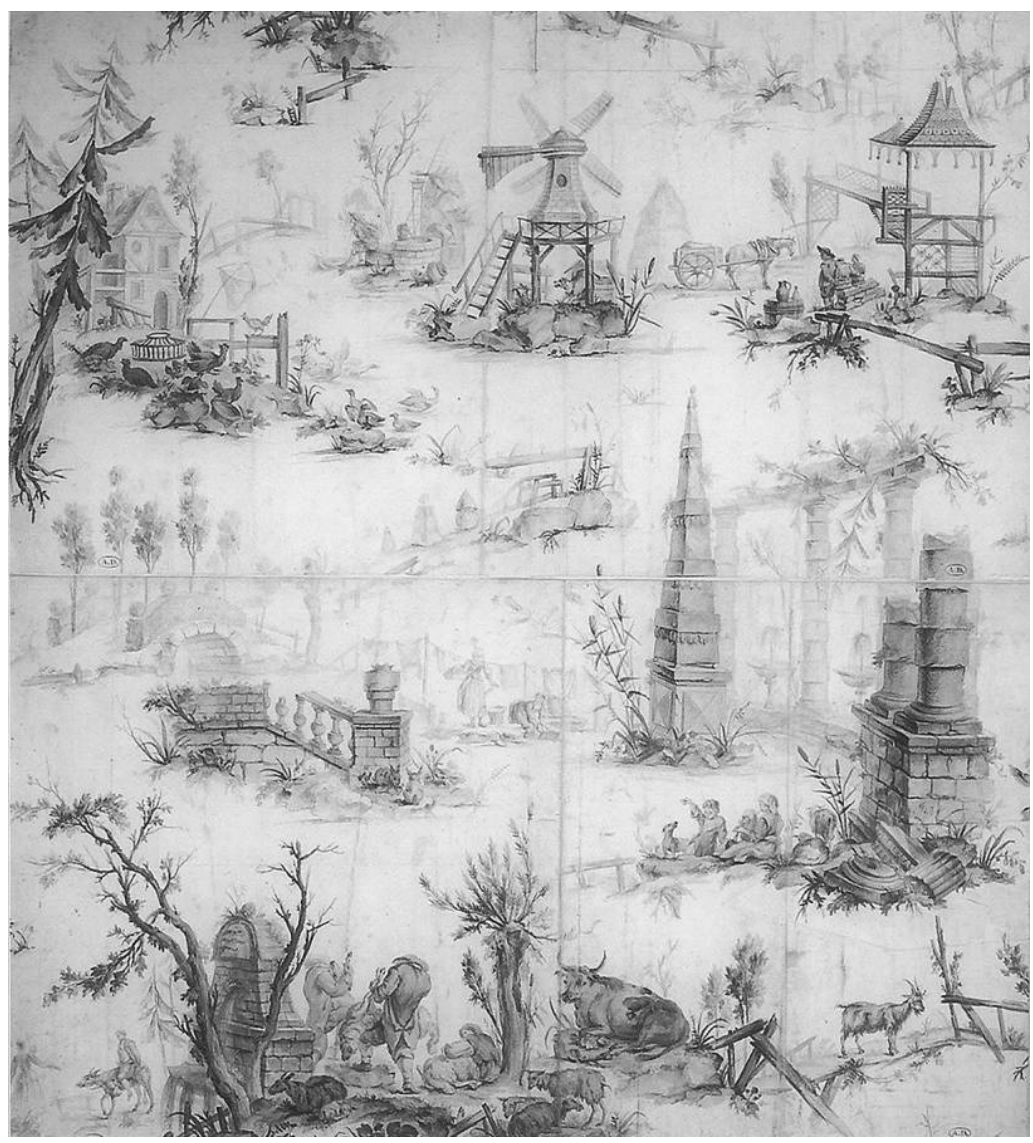

at a loss because, as he specified to a shopkeeper in 1795, "on the furniture of the American revolution there is a figure representing France with a crown on its head and a globe on which are three fleurs-de-lys. This is why I am setting it at four pounds per length below cost. It is up to you to judge if you want it or not." 66 With the decree of September 16, 1792, however, all of the signs representing the monarchy had to be destroyed, among them the coats of arms and the emblems of royalty. The theme of the American War of Independence remained acceptable, however, in accordance with the ideas of a France at once revolutionary and conquering. This is why, beginning in 1798, Oberkampf reprinted this design, while deleting the royal insignia (the fleurs-de-lys and the royal crown). The fabric was once again designated by its original title: L'Union de la France à l'Amérique. ${ }^{67}$

Once printed fabrics went out of style for different reasons, Oberkampf did not hesitate to engrave new plates or change a few details to 


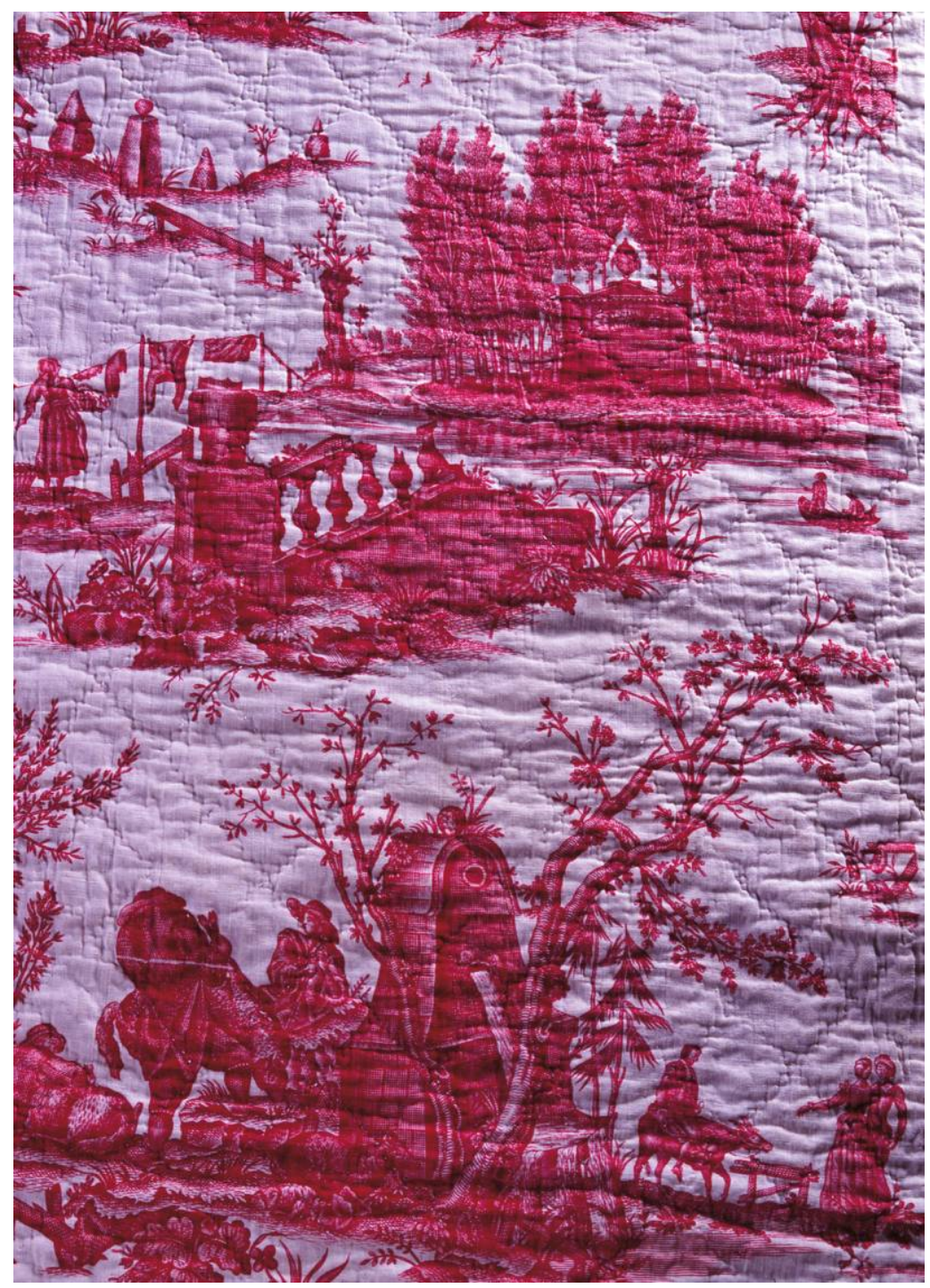

continue the printing of textiles, recycling the design at a lower cost. He proceeded in this manner for the textiles with balloon decorations, the fashion for which began to fade after 1787. Beginning in 1790, in Le Parc $d u$ château, the aereostatic balloon (see Fig. 1) was replaced by a hunter's shack and a fox in the rustic spirit of other motifs (Fig. 19). The fabric thus presents a charming composition of pastorals and little scenes in a garden. Oberkampf then indicated to the merchants who ordered this fabric that he "got rid of the balloon in the plate." 68 By suppressing Charles and Robert's balloon, Oberkampf removed any reference to an
FIGURE 21

Le Tombeau de Jean-Jacques Rousseau, 1779. Printed cotton, 95 x $93 \mathrm{~cm}$. Musée de la Toile de Jouy. Photo: Marc Walter. 
outdated fashion. Balloon fans could still order Le Ballon de Gonesse, however (Fig. 3). Oberkampf preserved the diversity of upholstery compositions he offered customers, but above all he continued to print this design, whose antique ornaments and little scenes in nature were still in fashion, saving money by not engraving a new design.

\section{Adaptation to Current Events during Engraving}

The comparison of preserved designs with their printed fabrics reveals certain last-minute additions and modifications in order to offer customers new and up-to-date themes. Oberkampf thus printed a fabric in homage to Jean-Jacques Rousseau simply by adding the monument to Rousseau built by the marquis de Girardin on the island of poplars in the park of Mortefontaine at Ermenonville to an existing design of ruins and countryside derived from Hubert Robert. The addition of this monument did not transform the overall composition because it merely replaced another motif, but it evoked the death of the famous person and secured the success of this fabric, now sold with the title Le Tombeau de JeanJacques Rousseau. ${ }^{69}$ Of course, Oberkampf carefully chose a design that would correspond with the taste for nature and country life described by the philosopher in La Nouvelle Héloise. The monument therefore is perfectly integrated into the landscape (compare Figs. 20-21).

Oberkampf proceeded the same way with Liberté américaine. In the design (Fig. 22), the round medallions are decorated with cupids. In the textile (Fig. 10), however, the medallions refer to American independence. Oberkampf probably decided to make this transformation at the moment of engraving, because he knew that his allusion to the War of Independence would render this fabric more desirable as it was above all more up-to-date.

Comparing printed fabrics with the compositions by artists and with archival documents reveals the changes that designs underwent before or during their printing on fabrics. These modifications could range from a simple change in title to the replacement or deletion of motifs as Oberkampf adapted designs to recent events and to changes in taste. His creation of printed cotton based on contemporary events may seem at first glance to be bad business: he profited most from a production sold to the greatest number of people for the longest possible period, and he knew that topical compositions ran the risk of going out of fashion more or less quickly. Documents concerning his intentions in the choice of such themes do not exist. Nevertheless, his fabrics with current themes 


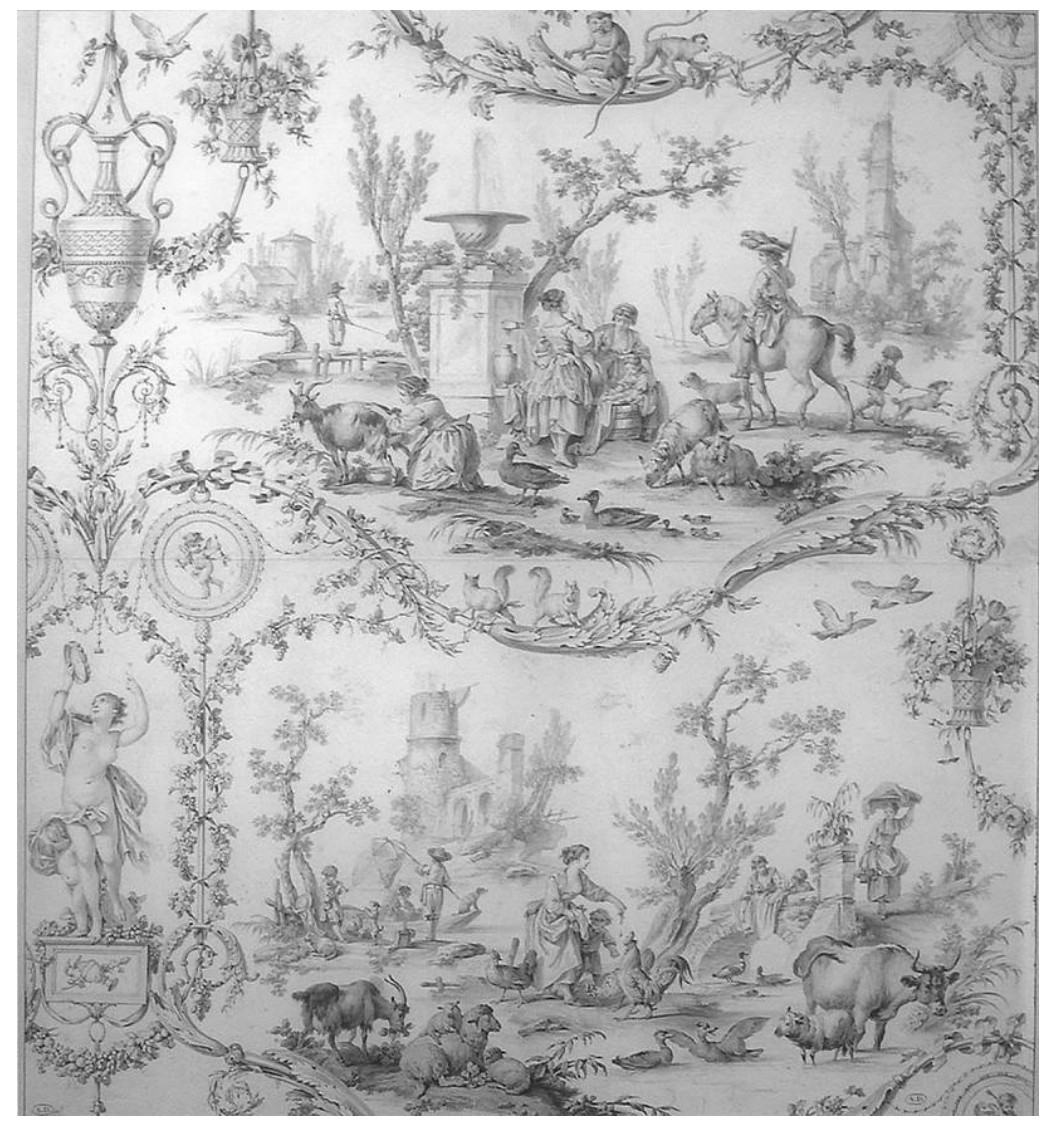

represented only a small portion of his monochrome upholsteries, and they were designed to attract the attention of customers aware of the most important current events and the effects of fads. Moreover, the manufacturer never took too great a risk, because the chosen subjects were never completely new, always being drawn from widely known events amply illustrated in the visual arts, and they were therefore likely to attract many customers. Topical themes were thus another source of decorative invention for Oberkampf's designers, contributing to the economic demand he fostered by regularly offering new designs.

The updating of monochrome upholsteries did not mean the abandonment of earlier designs. Compositions were printed for a number of years to make the cost of the engraving profitable, but also because taste in the provinces changed more slowly than in Paris. The geographic proximity of Oberkampf's manufacturing plant to the capital, where its head offices were located, facilitated the supplying of Parisian merchants before their colleagues. Significant political and cultural events almost
FIGURE 22

Untitled drawing, attrib. to Jean-Baptiste Huet, 1783. Ink and gray wash on paper, 102.5 x 92 cm. Musée des Arts Décoratifs, Cabinet des Dessins, Paris. Photo: author. 
always took place in Paris, and Parisian customers were thus likely to be the first seduced by such designs. Oberkampf also knew how to renew his client base through his commercial tactics: certain designs continued to be printed on cheaper cotton at lower prices because a less wealthy and provincial clientele appreciated them. For example, L'Union de la France à l'Amérique and Liberté américaine were still being printed at the end of the eighteenth century and the beginning of the nineteenth on ordinary fabrics. ${ }^{70}$ The success of these designs more than twenty years after the events they allude to may seem curious. In fact, their motifs could no longer be perceived as reflecting current incidents, but rather as representing historic events. At the same time, new compositions such as the dessin égyptien or Tancrède et Herminie referred to history as well-the places and styles of storied regions - which proved the best way to ensure their success in the long run.

-Translated by Pamela J. Warner

\section{NOTES}

1. Daniel Roche, Le peuple de Paris (1st ed. 1981; Paris, 1988), 298.

2. The import of printed fabrics as well as French production was the object of a ban engineered by the Lyonnais silk lobby between 1686 and 1759 . Archives Nationales, Paris, ADXI/52 Arrêt du Conseil d'État of October 26, 1686. See Serge Chassagne, La manufacture de toiles imprimées de Tournemine-Les Angers, étude d'une enterprise et d'une industrie au 18ème siècle (Paris, 1971), 38-41.

3. This technique was perfected in Ireland in 1752 by Francis Nixon. It was then developed from 1756 on in England. In the 1760s, it was used in Switzerland, whence it spread into France. See Serge Chassagne, Oberkampf, un entrepreneur capitaliste au siècle des Lumières (Paris, 1981), 70 and 74 .

4. For more detail on the economic, social, and technical history of the Jouy factory, see Chassagne, Oberkampf, un entrepreneur.

5. Regarding the ensemble of products and creations by the Jouy factory, see Josette Brédif, Toiles de Jouy (Paris, 1989) (in English as Toiles de Jouy: Classic Printed Textiles from France 1760 1843 [London and New York, 1989]), and, more recently, Mélanie Riffel and Sophie Rouart, Toile de Jouy (Paris, 2003) (in English as Toile de Jouy: Printed Textiles in the Classic French Style [London and New York, 2003]).
6. For more precision in the terminology of printed fabrics and in particular for the "toile de Jouy," see Aziza Gril-Mariotte, "Histoire de vocabulaire: Les appellations des toiles imprimées du 16e siècle à nos jours," in Histoire de la recherche textile: Développement des méthodes et outils de recherche, études et découvertes marquantes dans ce domaine (Conference Organized on the Fiftieth Anniversary of the Centre International d'Étude des Textiles Anciens, Lyon, September 26-29, 2005), Bulletin du CIETA, forthcoming.

7. "Il faudroit pouvoir lire dans l'avenir pour savoir quel genre succèdera à celui qui existe alors car de tous temps il y a eu un genre plus recherché que les autres et cela sera toujours. Le plus habile est aussi celui qui sait s'y arrêter à temps pour en avoir le moins de reste quand ce genre cesse de plaire." From an undated manuscript by Oberkampf left unfinished at his death in 1814, titled "Opinion d'Oberkampf fondateur des Manufactures de Jouy et d'Essones sur leur prosperité et leur conservation," Archives Nationales, Centre des Archives du Monde du Travail, Roubaix (hereafter A.N., C.A.M.T.), 41AQ1.83.

8. Gottlieb Widmer, "Mémorial de la manufacture de Jouy," 1859, 27. Unpublished manuscript in a private collection; typescript transcription at the Musée de la Toile de Jouy. 
9. Laure Hug, "Catalogue raisonné de l'oeuvre peint de Jean-Baptiste Huët (1745-1811)" (Ph.D. diss., Université Paris IV-Sorbonne, 1997), 4-8. The author did not integrate the drawings made for the Jouy factory held in the Musée des Arts Décoratifs, Cabinet des Dessins, Paris, into his catalogue of Huet's paintings and drawings. On the other hand, extracts of letters sent by Oberkampf to the painter held in the archives of the factory were placed in an appendix.

10. For the years between 1790 and 1821, the active correspondence was kept with the other archives of the factory, which is the property of Oberkampf's heirs. They are currently deposited with the Archives Nationales at the Centre des Archives du Monde du Travail in Roubaix. Serge Chassagne, Oberkampf, un entrepreneur, already combed through these documents for his portrait of the manufacturer Oberkampf and the economic history of the factory. I would like to thank him for having encouraged me to pursue information that he did not use regarding the designers, the creation of designs, and the marketing and sale of motifs. The Musée de la Toile de Jouy, Jouy-en-Josas, holds other archives, notably 1,048 letters placing orders, often accompanied by samples dated from 1790 and 1821 (inv. 980.12), but they only rarely concern monochromes with figures.

11. A.N., C.A.M.T., 41AQ1.83): "faciliter la vente de laquelle dépend la prospérité de l'établissement."

12. Brédif, Toiles de Jouy; Mélanie Riffel and Sophie Rouart, Toile de Jouy. La fête et les jeux en toile de Jouy, exh. cat. (Jouy-en-Josas: Musée Oberkampf, 1987); Josette Brédif, L'histoire vue à travers la toile imprimée, exh. cat. (Jouy-en-Josas: Musée Oberkampf, 1982); Josette Brédif, Les indiennes de la manufacture de Jouy-en-Josas, exh. cat. (Jouy-enJosas: Musée Oberkampf, 1982); anon., Toiles de Jouy, dessins et cartons de J.-B. Huet (1745-1811), exh. cat. (Mulhouse: Musée de l'Impression sur Étoffes, 1970); Josette Brédif, Toiles de Jouy, exh cat. (Jouy-en-Josas: Musée Oberkampf, 1977).

13. Riffel and Rouart, Toile de Jouy (2003), 59-73.

14. The designs were titled by the designer, the producer, or by common usage. Often the names used today for the fabrics differ from those used in the sources.

15. All producers used a numbering system to designate each design and facilitate the identification of textiles for orders. The number was inscribed on the factory mark printed on the fabric, or "chef de pièce" (that section of fabric where the factory mark was printed at the edge). The number was assigned before the production of the plate. Oberkampf sent his clients a printed list with the numbers of the designs and the titles of the available upholstery fabrics depicting figures. Merchants could then place their order by indicating the number and/or the title of the textile. Unfortunately, the archives do not contain a document regularly updated with the names of new designs. This commercial practice was widespread in other factories printing upholstery fabrics from copperplates, e.g., Favre Petitpierre in Nantes, for which a list of this type exists, published by Henri-René d'Allemagne, La toile imprimée et les indiennes de traite (Paris, 1941), 112-14. By reassembling Oberkampf's numbers printed on the cottons, those cited in the archival documents (the design numbers all begin with the letter "D"), and the indications of date, it is possible to establish in part the list of upholstery with figures and therefore a chronology of designs at the moment of their creation.

16. Maryse Thébaud-Sorger, "L'air du temps, l'aérostation: Savoirs et pratiques à la fin du $18 \mathrm{e}$ siècle" (Ph.D. diss., École des Hautes Études en Sciences Sociales, Paris, 2004).

17. A.N., C.A.M.T., 41AQ82.212. On November 19, 1790, Oberkampf answered a letter from Dijon: "Je n'ai plus du dessin du Ballon que vous me demandez; j'en ai d'un autre D No108 [Le Parc du Château]. J'ai la planche $\mathrm{N}^{\circ} 166$ du Ballon de Goneze [sic] et dont je ne fait que sur commande."

18. Ibid.

19. This wallpaper recently appeared at auction in Paris. See Papiers peints anciens, Drouot-Richelieu, sale catalogue, May 31, 2006, expert Xavier Peticol, p. 17 , notice 69

20. A.N., C.A.M.T., 41AQ82.212, letter from Oberkampf to the merchant Thomas in Dijon, November 19, 1790.

21. Maryse Thébaud-Sorger, "Les premiers ballons et la conquête du ciel, les dimensions d'une découverte," Dix-huitième Siècle 31 (1999), 157-77.

22. Véronique Wiesinger, ed., Les Américains et la Révolution française, exh. cat. (Blérancourt: Musée National de la Coopération Franco-Américaine, 1989), 45.

23. Design D91, printed in 1780 , probably dates to 1779 (see Widmer, Mémorial de la manufacture, 97). It can therefore be deduced, based on the fact that Oberkampf printed two or three pieces of upholstery with figures annually, that design D95 was printed the following year. The identification of the citadel of La Rochelle was made by Brédif, Toiles de Jouy, 141; she dates this motif around 1783, however, because of the signature of the Treaty of Versailles.

24. The drawing is in the Cabinet des Dessins, Musée des Arts Décoratifs in Paris, inv. CD2854.

25. A.N., C.A.M.T., 41AQ84.892, 16 Ventôse, Year 7 (February 4, 1799): "J'ai du dessin de L'Union de la France à l'Amérique." The titles of the fabrics sometimes undergo slight modifications in the manufacturer's correspondence. It is only from the 1800 s that the titles of the fabrics acquire greater importance: they are then printed next to the logo of the producer.

26. Iconologie ou explication nouvelle de plusieurs images, emblèmes et autres figures . . . tirée des recherches et figures de Cesar Ripa, moralisée par Baudoin (1644 2nd ed., Paris, 1664), 6-10: "Les quatre parties du Monde:" "L'EUROPE. Cette partie du monde qui excelle par dessus toutes les autres, nous est figurée par une Dame royalement vestuë. . . Elle porte sur la teste une riche couronne.... Un cheval est remarquable auprès d'elle, avec quantité de Trophées, \& d'Armes de toutes sortes. . . L La couronne qu'elle porte fait foir que l'Europe a toujours eu le principal advantage sur les autres parties de l'Univers, dont elle a triomphé comme Reine... Le Sceptre qu'elle porte est le Symbole de la puissance, à cause qu'en son enclos tiennent leur Court les plus grands Princes du Monde.... Par le Cheval \& les Armes qui se voyent à l'entour d'elle, il est denoté qu'elle a toujours emporté le prix en matières des nobles connaissances, $\&$ des exercices de guerre."

27. Ibid. "L'AMERIQUE. Cette femme qui a le teint olivatre ...\& un voile de plusieurs couleurs qui lui couvre le corps à demy, représente l'Amérique. Outre qu'une écharme de plumes tresagreables, artistement jointes ensemble, la fait particulièrement remarquer par ce bisare ornement: elle porte en une main une flèfche, en l'autre un arc, \& un carquoi à ses costez. A quoy l'on peut ajouster qu'elle a sur sa teste une guirlande de plusieurs plumes estranges, $\&$ à ses pieds un espèce de Lezard ressemblant à peu pres à un Crocodyle. Comme encore une teste humaine arrachée de son corps, \& traversée d'un dard."

28. In textile printing, the repeat designates the height of the design by the width, which is repeated as many times as necessary on the cotton. Most difficult for the designer and printer is to conceal the joints between the repeats. 
29. A.N., C.A.M.T., 41AQ86.151, 7 Fructidor, Year 9 (August 25, 1801). Oberkampf could not meet the demand for design 95 in blue or violet, so he offered to send another design or to wait until he could reprint it. 41AQ87.9. On 24 Floréal, Year 11 (May 14, 1803), he shipped six pieces in red of this design to a client from Bayonne.

30. Riffel and Rouart, Toile de Jouy (2003), 69

31. A.N., C.A.M.T., 41AQ1.83, "Opinion d'Oberkampf fondateur des Manufactures de Jouy et d'Essones sur leur prospérité et leur conservation."

32. The Treaty of Versailles put an end to the hostilities among the United States, England, and France; and England recognized the independence of its former colonies.

33. The identification of these motifs was made by Brédif, Toiles de Jouy, 140.

34. Book III, ode IV, verse 10, Odes d'Horace traduites en vers français avec le texte en regard et des notes (Paris, 1831), 282.

35. Rosine Trogan and Philippe Sorel, Augustin Dupré (1748-1833), graveur général des Monnaies de France: Collections du Musée Carnavalet (Paris, 2000), 17.

36. The original design number D103 on the drawing for L'Indépendance américaine, in the Cabinet des Dessins, Musée des Arts Décoratifs, in Paris, situates its creation around 1784

37. A.N., C.A.M.T., 41AQ85.177, 23 Brumaire, Year 8 (November 14, 1799). At the end of 1799 , Oberkampf announced to his merchants that he could offer them "un assortiment assez complet tant en bleu qu'en rouge," of monochrome upholstery fabric. Among the designs listed are L'Union de la France à l'Amérique and Liberté américaine.

38. Philippe Bordes, "L'art et le politique," in Aux armes et aux arts! Les arts de la Révolution 1789. 1799, ed. Philippe Bordes and Régis Michel, exh. cat. (Paris: Musée Carnavalet, 1988), 107-8. Hubert Robert (1733-1808), La Bastille dans les premiers jours de sa démolition, 20 juillet 1789, oil on canvas, 77 x 114 cm, Musée Carnavalet, Paris.

39. A.N., C.A.M.T., 41AQ18, account book of the manufacturer from January 18, 1790, to Floréal, Year 2 (April 20-May 19, 1794).

40. A.N., C.A.M.T., 41AQ82.459. On August 8, 1791, Oberkampf wrote to a correspondant in Bordeaux: "Il y a de nouveaux desseins ... celui de la Fédération qui n'est pas encore finie d'être gravé."
41. Riffel and Rouart, Toile de Jouy (2003), 72.

42. Hubert Robert, Fête de la Fédération au Champde-Mars, 14 juillet 1790, 1790, oil on canvas, $52 \mathrm{x}$ 96 cm, Musée National du Château de Versailles.

43. A.N., C.A.M.T., 41AQ83.628, 9 Ventôse, Year 3 (February 27, 1795).

44. Merchants regularly purchased monochromes with figures on receiving a specific order. In such cases they specified the design, the number of pieces, and the color that their private customers or their upholsterers desired.

45. The manufacturer's accounts detail the price of the engraving compared to the amount paid for a drawing. For example, the engraving of the design of Paul et Virginie cost six hundred francs, while the drawing cost three hundred. A.N., C.A.M.T., 41AQ20, account book of the factory from Floréal, Year 8, to Vendémiaire, Year 14 (April 20-May 19, 1800, to September 22-October 21, 1805)

46. Paul et Virginie appears in its definitive version in the last volume of the Études de la nature (1784. 1788); subsequently the novel was edited separately as Paul et Virginie avec figures (Paris, 1789). The immediate success of the work led Bernardin de Saint-Pierre to print a second, very luxurious version in 1806, with the publisher Didot.

47. A.N., C.A.M.T., 41AQ20. The design was engraved in the summer of 1803, and was paid for in the month of Brumaire, Year 12 (October 1803).

48. Aux armes et aux arts!, ed. Bordes and Michel, 23. Le Naufrage de Virginie à l'île de France, Salon of 1789, oil on canvas, $87 \times 130 \mathrm{~cm}$, Hermitage Museum, St. Petersburg.

49. A.N., C.A.M.T., 41AQ89.656, August 31, 1807.

50. In 1802, Dominique-Vivant Denon's account, Voyage dans la Basse et la Haute Égypte pendant les campagnes du général Bonaparte, appeared, accompanied by numerous drawings by the author. Then, beginning in 1809, Napoleon's monumental Description de l'Égypte was published by the imperial press, a true encyclopedia of knowledge acquired about pharaonic and Greco-Roman antiquity, natural history, and Egyptian society of the period. It would ultimately number twenty volumes, published between 1809 and 1828 .

51. Denon, Voyage dans la Basse et la Haute Égypte, pl. 2.
52. A.N., C.A.M.T., 41AQ90.337, September 17, 1808.

53. François Pupil, Le style troubadour ou la nostalgie du bon vieux temps (Nancy, 1985), 49.

54. www.gallica.bnf.fr

55. Tasso, La Gerusalemme Liberata (Paris, 1784 1786); and Tasso, La Jérusalem délivrée. Nouvelle édition revue et corrigée et enrichie de la vie du Tasse ornée de son portrait et de vingt belles gravures (Paris, 1803).

56. Publication of other editions of Paul et Virginie, especially the successful edition of 1806 , and above all the spread of this theme to the visual arts and to other manufacturers of printed fabrics take place after the Jouy design appeared. On illustrations of La Gerusalemme Liberata in the nineteenth century, see Les belles infidèles de la Jérusalem délivrée, la fortune $d u$ poème $d u$ Tasse XVIe-XXe siècles (Proceedings of the International Colloquium at Aixen-Provence, October 24-26, 2002, Aix-en-Provence: Publications de l'Université de Provence, 2004).

57. A.N., C.A.M.T., 41AQ86.572, July 9, 1802.

58. A.N., C.A.M.T., 41AQ91.178, October 31, 1809: "Je ne puis vous offrir qu'un seul dessin Tancrède \& Herminie sujet tiré de la Jérusalem délivrée, il est sur toile fine au prix de $7 \mathrm{f}$ l'aune."

59. A.N., C.A.M.T., 41AQ91.282, January 10, 1810: "Le meuble Tancrède et Herminie dont vous me parlez est un de mes dessins les plus nouveaux. Je le vends $7 f$ l'aune \& il est imprimé sur qualité superfine. J'ai bon nombre d'autres dessins mais dont je manque actuellement. Je vous les ferai établir pour l'été prochain. Les prix en seront plus modérés que celui ci-dessous \& varieront selon la qualité de la toile."

60. Brédif, Toiles de Jouy, 128.

61. Oberkampf and others provided l'impression à façon, which consists of printing fabrics at the expense of merchants, who pay only the cost of the printing. This sales procedure was not without its inconveniences, and Oberkampf limited it from 1790 to copperplate designs because it allowed him to profit even more from the engraving of a design.

62. A.N., C.A.M.T, 41AQ82.113, letter from Oberkampf to the Frères Berthault \& Cie of Nantes, June 28, 1790: “le Dessin n¹40 s'appelle 
le dessein de la Révolution, je vous prie de le vendre sous ce nom."

63. Musée de la Toile de Jouy-en-Josas, 980.12.164, letter from Vincent Thoré in La Flèche to Oberkampf, September 21, 1791.

64. A.N., C.A.M.T, 41AQ83.116, letter from Oberkampf to Pont Rainaldis \& Cie in Lyon, March 14, 1793: "Il me reste très peu de dessin de la fédération et révolution \& je continue à les vendre au même prix que les autres meubles."
65. A.N., C.A.M.T, 41AQ83.572, letter from Oberkampf to Cretel in Rouen, 12 Frimaire, Year 3 (December 2, 1794).

66. A.N., C.A.M.T., 41AQ83.606, 3 Pluviôse, Year 3 (January 22, 1795): "Sur le meuble de la Révolution d'amérique il existe une fig. représentant la France par une couronne sur la tête et un globe sur lequel sont trois fleurs de lys. C'est ce qui me le fait établir 4 livres par aune en dessous du cours c'est à vous de juger si vous en voulez ou non."
67. A.N., C.A.M.T., 41AQ84.892, 16 Ventôse, Year 7 (February 4, 1799).

68. A.N., C.A.M.T., 41AQ82.212 and 224, November 19 and December 6, 1790.

69. A.N., C.A.M.T., 41AQ87.217, September 7, 1803.

70. A.N., C.A.M.T., 41AQ86.151, order placed by Fourgassié in Castres on August 25, 1801, and 41AQ87.9, order placed by Josué Léon on May 14, 1803. 